\title{
Therapeutic approaches in heart failure with preserved ejection fraction: past, present, and future
}

\author{
Jan Wintrich ${ }^{1} \cdot$ Ingrid Kindermann $^{1} \cdot$ Christian Ukena ${ }^{1} \cdot$ Simina Selejan $^{1} \cdot$ Christian Werner $^{1} \cdot$ Christoph Maack $^{2}$.

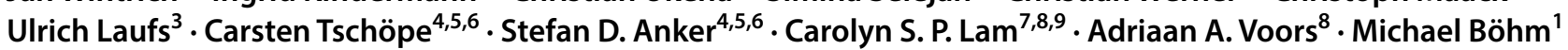

Received: 14 January 2020 / Accepted: 11 March 2020 / Published online: 31 March 2020

(c) The Author(s) 2020

\begin{abstract}
In contrast to the wealth of proven therapies for heart failure with reduced ejection fraction (HFrEF), therapeutic efforts in the past have failed to improve outcomes in heart failure with preserved ejection fraction (HFpEF). Moreover, to this day, diagnosis of HFpEF remains controversial. However, there is growing appreciation that HFpEF represents a heterogeneous syndrome with various phenotypes and comorbidities which are hardly to differentiate solely by LVEF and might benefit from individually tailored approaches. These hypotheses are supported by the recently presented PARAGON-HF trial. Although treatment with LCZ696 did not result in a significantly lower rate of total hospitalizations for heart failure and death from cardiovascular causes among HFpEF patients, subanalyses suggest beneficial effects in female patients and those with an LVEF between 45 and 57\%. In the future, prospective randomized trials should focus on dedicated, well-defined subgroups based on various information such as clinical characteristics, biomarker levels, and imaging modalities. These could clarify the role of LCZ696 in selected individuals. Furthermore, sodium-glucose cotransporter-2 inhibitors have just proven efficient in HFrEF patients and are currently also studied in large prospective clinical trials enrolling HFpEF patients. In addition, several novel disease-modifying drugs that pursue different strategies such as targeting cardiac inflammation and fibrosis have delivered preliminary optimistic results and are subject of further research. Moreover, innovative device therapies may enhance management of $\mathrm{HFpEF}$, but need prospective adequately powered clinical trials to confirm safety and efficacy regarding clinical outcomes. This review highlights the past, present, and future therapeutic approaches in HFpEF.
\end{abstract}

Keywords Heart failure · Preserved ejection fraction · Pharmacotherapy in HFpEF · LCZ696 · Device therapy

Jan Wintrich

Jan.Wintrich@uks.eu

1 Klinik für Innere Medizin III-Kardiologie, Angiologie und Internistische Intensivmedizin, Universitätsklinikum des Saarlandes und Medizinische Fakultät der Universität des Saarlandes, Kirrberger Straße, 66421 Homburg/Saar, Germany

2 Comprehensive Heart Failure Center (CHFC), University Clinic Würzburg, Würzburg, Germany

3 Klinik und Poliklinik für Kardiologie im Department für Innere Medizin, Neurologie und Dermatologie, Universitätsklinikum Leipzig, Leipzig, Germany

4 Department of Cardiology, Universitätsmedizin Berlin, Charite, Campus Rudolf Virchow Clinic (CVK), Augustenburger Platz 1, 13353 Berlin, Germany
5 German Center for Cardiovascular Research (DZHK), Partner Site, Berlin, Germany

6 Berlin-Brandenburg Institute of Health/Center for Regenerative Therapies (BIHCRT), Berlin, Germany

7 National Heart Centre, Singapore and Duke-National University of Singapore, Singapore, Singapore

8 University Medical Centre Groningen, Groningen, The Netherlands

9 The George Institute for Global Health, Sydney, Australia 


\section{Introduction}

Heart failure (HF) poses a growing burden for health systems worldwide as incidence and prevalence is rising annually. Typically, the term HF was applied to patients with reduced ejection fraction only, until the first reports on patients suffering from symptoms of HF despite having normal left-ventricular ejection fraction (LVEF) and small hearts emerged [1-3]. Initially, the condition was referred to as "diastolic heart failure" according to the different appearance compared to "systolic heart failure". However, this has led to discussions among the scientific community, since a clear differentiation between systolic and diastolic dysfunction is rather hypothetical than physiological [4]. It was even shown that severity of diastolic dysfunction may be greater in patients with impairment of systolic function than in those without [5] and that systolic dysfunction can also be detected in patients with preserved ejection fraction [6]. Therefore, the European Society of Cardiology (ESC) focused on objective findings and proposed the term "heart failure with preserved ejection fraction" (HFpEF). In the latest 2016 guidelines, $\mathrm{HF}$ is differentiated in three different forms depending on LVEF: HFpEF (LVEF $\geq 50 \%$ ), HFrEF ("heart failure with reduced ejection fraction", LVEF $<40 \%$ ), and HFmEF ("heart failure with mid-range ejection fraction", LVEF $>\geq 40$ and $<50 \%$ ) [7]. In contrast to the latest advances in therapy of HFrEF, HFpEF remains a challenge, in which many established HF drugs have failed to improve prognosis. This review highlights the main epidemiological and pathophysiological aspects in HFpEF and discusses dilemmas in management of HFpEF as well as promising therapeutic options for the future.

\section{Dilemma in diagnosing HFpEF}

HFpEF mostly affects older patients, predominantly females. Depending on various factors (e.g., definition and time of publication), the proportion of HFpEF among HF patients ranges from 22 to $73 \%$ [7]. Patients with HFpEF are a heterogeneous group with numerous underlying aetiologies and pathophysiological abnormalities [7]. Thus, diagnosis of HFpEF can be challenging, as it rather describes a clinical syndrome than a single clinical diagnosis [8]. Also, there have been debates whether the definition of HFpEF should be based solely on LVEF, since LVEF-based HF subgroups may exhibit significantly overlapping phenotypes [9]. This issue has resulted in proposition of diagnostic algorithms which take various diagnostic measures such as clinical characteristics, laboratory and echocardiographic findings, as well as sophisticated imaging modalities and invasive haemodynamic measurements into account. For instance, a composite HFpEF score determined by presence of atrial fibrillation, obesity, age $>60$ years, treatment with $\geq 2$ antihypertensives, echocardiographic $E / e^{\prime}$ ratio $>9$, and echocardiographic pulmonary artery systolic pressure $>35 \mathrm{mmHg}$ has been shown to substantially identify patients at high risk of HFpEF that should undergo further evaluation [10]. According to the updated consensus recommendation by the Heart Failure Association (HFA) of the ESC [8], a step-wise diagnostic process should be applied in patients with suspected HFpEF. After an initial work-up based on clinical parameters and non-invasive tests (e.g. ECG, echocardiography, blood tests), the authors suggest a risk stratification by using the 'HFA-PEFF' score in selected patients. In this score, patients are stratified in three different groups (low risk, intermediate risk, and high risk) according to echocardiographic parameters and biomarker levels. While patients identified as high risk should be diagnosed with HFpEF, patients at intermediate risk should undergo echo stress tests or if inconclusive, invasive haemodynamic measurements, to establish the diagnosis of HFpEF. Finally, the authors recommend an aetiological work-up which includes ergometry, blood tests, genetic testing, imaging modalities (particularly cardiac magnetic resonance imaging), and, in rare cases, myocardial biopsy. This suggested exclusion of specific causes in the etiology of HFpEF, for example primary cardiomyopathies and storage diseases such as M. Fabry and amyloidosis, as well as pericardial diseases such as constrictive pericarditis, may be crucial for an individually tailored specific treatment of the HFpEF syndrome. For instance, initiation of tafamidis in transthyretin amyloid cardiomyopathy is of great importance, as these patients suffer from a poor prognosis [11]. If untreated, the median survival time of patients with a wild-type transthyretin amyloidosis is 3.6 years after diagnosis and 2.5 years with a hereditary transthyretin amyloidosis $[12,13]$. The benzoxazole derivative tafamidis prevents amyloidogenesis by binding to the thyroxine-binding sites of transthyretin. In the recent Transthyretin Amyloidosis Cardiomyopathy Clinical Trial (ATTR-ACT) including 441 patients with transthyretin amyloid cardiomyopathy, therapy with tafamidis led to a significant reduction in all-cause mortality and rate of CV hospitalizations compared to placebo [14]. 


\section{Current understanding of pathophysiological mechanisms in HFpEF}

Currently, the precise pathophysiological processes in HFpEF are incompletely resolved, since animal models are sparse. This is due to a high prevalence of comorbidities in HFpEF patients, which is difficult to be translated into animal models, which are typically younger and less comorbid [4]. However, there is consensus that HFpEF is associated with systemic inflammation [15], which is triggered by the cumulative expression of various risk factors and comorbidities (Fig. 1). If no specific disease is the cause, the most common risk factors/comorbidities of

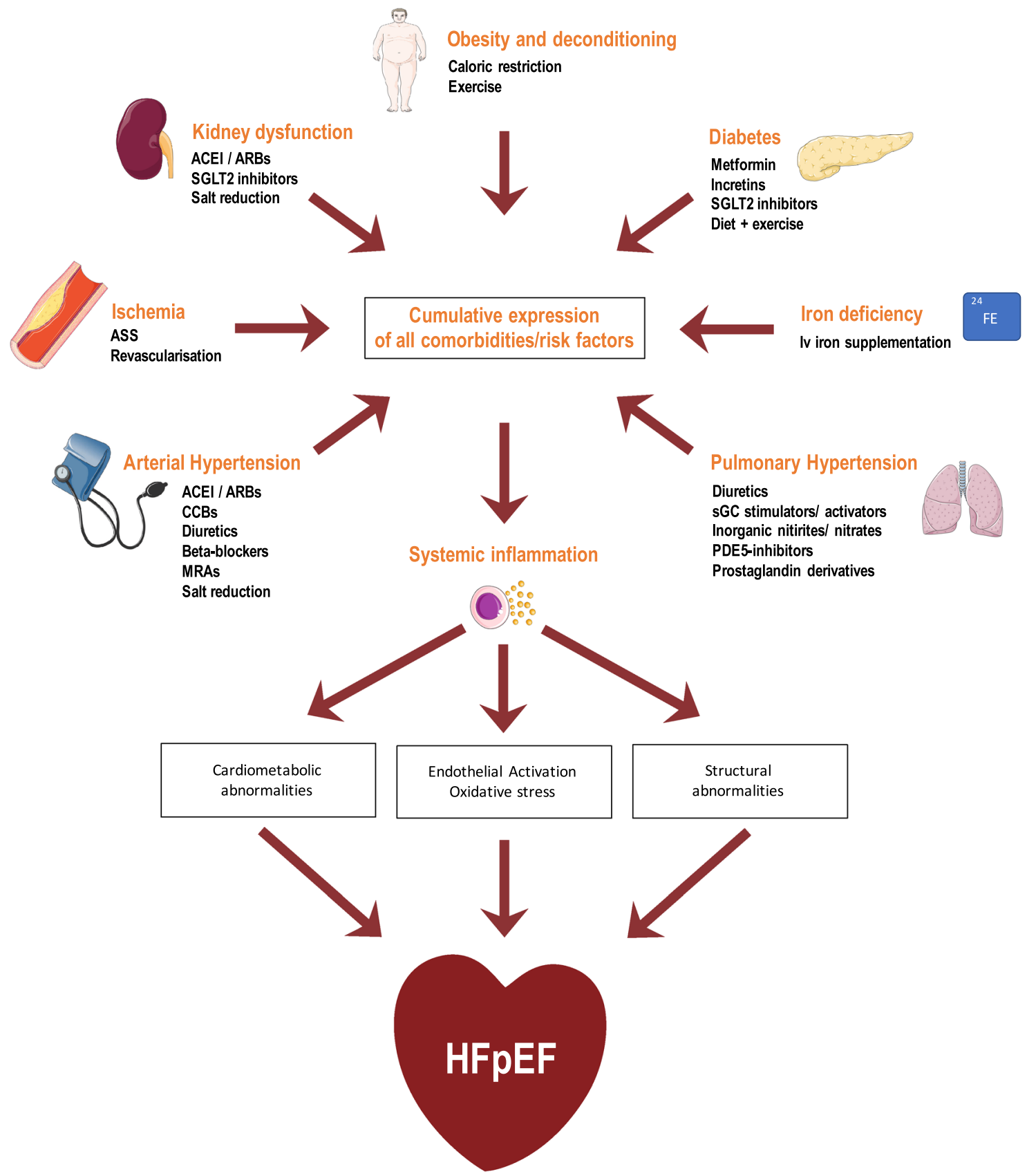

Fig. 1 Current model on pathophysiology and management of comorbidities and risk factors in HFpEF. Cumulative expression of the shown comorbidities and risk factors can cause systemic inflammation which can then lead to development of HFpEF [2]. ACEI angiotensin-converting enzyme inhibitor, $A R B$ angiotensin recep- tor blocker, $C C B$ calcium channel blocker, $M R A$ mineralocorticoid receptor antagonist, $P D E 5$ hosphodiesterase-5, $s C G$ soluble guanylate cyclase, $S G L T 2$ sodium-glucose cotransporter-2. Figure modified according to Tschöpe et al. [4] and Lam et al. [9] 
HFpEF are age, female gender, renal impairment, diabetes, hypertension, as well as obesity and deconditioning [16]. Typically, in contrast to HFrEF patients, patients suffering from HFpEF are older, have a higher average body mass index, are more likely to be female, and exhibit a lower prevalence of ischemic heart disease [17]. Activation of the endothelium through the systemic inflammatory state eventually causes oxidative stress [18]. As a consequence, reactive oxygen species (ROS) directly react with nitric oxide (NO) and reduce its bioavailability. In addition, ROS may cause eNOS uncoupling which leads to production of highly reactive superoxide $\left(\mathrm{O}_{2}^{-}\right)$instead of NO. These processes result in a vasoconstricting, pro-inflammatory, and pro-thrombotic state of endothelial dysfunction [19]. Furthermore, alterations of both the myocytic and nonmyocytic compartment can increase diastolic stiffness and may contribute to development of $\operatorname{HFpEF}[20,21]$. For instance, reduction of NO bioavailability by oxidative stress and inflammatory cytokines downregulates the nitrogen monoxide-cyclic guanosine monophosphate-protein kinase G (NO-cGMP-PKG) pathway, and, therefore, decreases PKG activity. PKG plays an essential role in regulating phosphorylation, isoform switching, and oxidative modifications of the cytoskeletal protein titin, which mainly determines cardiomyocyte stiffness [22]. Besides cardiomyocyte stiffness, changes in the composition and structure of the non-myocytic compartment contribute to diastolic stiffness [19]. Endothelial dysfunction is associated with adherence and infiltration of monocytes and stimulation of integrated macrophages. By secretion of pro-fibrotic substances, in particular transforming growth factor $\beta$ (TGF- $\beta$ ) [23], these cells promote myofibroblast differentiation and eventually collagen secretion, leading to extracellular fibrosis [24, 25]. In addition, galectin-3, a lectin-binding galactoside, has been suggested to be another major mediator of myocardial fibrosis in HFpEF, which enhances collagen secretion by binding to myofibroblasts and may be in part responsible for the conferral of the detrimental effects of aldosterone [26, 27]. Moreover, myocardial fibrosis in HFpEF can result from hypertension, aging, metabolic triggers, and infrequently reparative processes [28]. Finally, cardiometabolic functional abnormalities, e.g., abnormal mitochondrial structure and function, change in substrate utilization and intracellular calcium overload, are thought to be another important pathomechanism in HFpEF, although these assumptions are primarily derived from studies in HFrEF [29].

\section{Treatment of HFpEF}

\section{Focus on comorbidities}

Clinical findings suggest that prognosis in patients with HFpEF is highly influenced by comorbidities [30-32]. This concept is addressed in the OPTIMIZE-HFpEF trial (NCT02425371). Thus, adequate treatment of comorbidities in HFpEF might be of crucial importance and patients should be regularly screened for these conditions [33] (Fig. 1). For instance, obesity and deconditioning are common risk factors in HFpEF. In a sub-analysis of the I-PRESERVE trial, $71 \%$ of all 4109 patients had a body mass index $\geq 26.5 \mathrm{~kg} / \mathrm{m}^{2}$ and $21 \%$ had a BMI between 23.5 and $26.4 \% \mathrm{~kg} / \mathrm{m}^{2}$ [34]. Moreover, the risk for the primary endpoint (death from any cause or hospitalization for a $\mathrm{CV}$ cause, that is, HF, myocardial infarction, unstable angina, arrhythmia, or stroke) was increased in patients with $\mathrm{BMI}<23.5 \mathrm{~kg} / \mathrm{m}^{2}$ and in those with BMI $\geq 35 \mathrm{~kg} /$ $\mathrm{m}^{2}$. Both physical activity (PA) and caloric restriction are important non-pharmacological approaches to reduce obesity and deconditioning and have shown to be associated with prognostic effects. In a post hoc analysis of the TOPCAT trial, risk of HF hospitalization and mortality was lower in physically high-active HFpEF patients than in intermediate-active and poorly active patients [35]. In the prospective Ex-DHF pilot trial, supervised exercise training (ET) improved exercise capacity and QOL and led to atrial reverse remodeling and reduction of diastolic dysfunction in HFpEF patients [36]. The ongoing Ex-DHF trial aims to evaluate long-term effects of supervised ET on a total of 320 patients [37]. Furthermore, prescription of a 20-week hypocaloric diet was associated with an increased peak $V \mathrm{O}_{2}$ in a cohort of 100 obese HFpEF patients, most of which were female (81\%). In addition, the effects were even greater when patients also had to join supervised exercise sessions three times a week, suggesting the combination of PA and diet to provide additive effects [38]. Another important comorbidity in HF patients is anemia due to iron deficiency [7]. In a small study with 190 symptomatic HFpEF patients, iron deficiency was present in $58.4 \%$ of all patients, while only 54 patients showed a corresponding anemia [39]. Interestingly, iron deficiency was significantly more prevalent in patients with severe diastolic dysfunction, and was associated with reduced exercise capacity and quality of life (QOL). Intravenously administered iron improves symptoms and QOL in patients with HFrEF [40]. Enhancing mitochondrial energy supply by iron supplementation has been discussed as one underlying mechanism, but whether this affects cardiac and/or skeletal muscles is currently unclear [41, 42]. Two current randomized-controlled 
trials (RCTs) (FAIR-HFpEF, PREFER-HF) focus on the effects of intravenously administered iron primarily on functional capacity in terms of six-minute walking distance (6MWD) as well as morbidity and mortality in HFpEF patients (NCT03074591, NCT03833336). Moreover, hypertension can cause recurring hospitalizations in HFpEF [43] and needs to be treated in accordance to the current hypertension guidelines [44]. Myocardial ischemia has also been frequently reported in HFpEF patients, contributing to greater deterioration in ventricular function and increased mortality [45]. Therefore, special emphasis should also be placed on adequate diagnostic measures and revascularization strategies. Additionally, atrial fibrillation (AF), the most common arrhythmia, often coexists with HFpEF [46]. According to a post hoc analysis of the TOPCAT trial, detection of AF represents an independent risk factor of adverse cardiovascular $(\mathrm{CV})$ outcome (composite endpoint of CV mortality, aborted cardiac arrest, or HF hospitalization) [47]. While catheter ablation of AF leads to increased survival rates compared to antiarrhythmic drug therapy in HFrEF [48, 49], it is currently unclear if these effects equally account for HFpEF patients [50]. In a small retrospective analysis, effects of catheter ablation on symptom burden, NYHA functional class, in-hospital adverse event rate, and freedom from recurrent atrial arrhythmia at 12 months were similar in $97 \mathrm{HFrEF}$ (LVEF < 50\%) and $133 \mathrm{HFpEF} \mathrm{(LVEF} \geq 50 \%$ ) patients [51]. However, adequately powered, randomized trials are necessary, to assess the value of AF ablation in the collective of HFpEF patients.

\section{Dilemmas in past HFpEF trials}

In past trials, there have been significant differences regarding the definition of HFpEF. In contrast to the ESC definition (LVEF $\geq 50 \%$ ), major clinical trials such as the TOPCAT trial [52] or the recent PARAGON-trial [53] have included patients with an LVEF $\geq 45 \%$. However, as mentioned, there are increasing concerns about defining HFpEF by LVEF only [9]. Furthermore, it is essential to acknowledge HFpEF as a heterogeneous syndrome most likely comprising various pathophysiological phenotypes which might need to be treated differently. Therefore, future clinical trials should focus on dedicated, well-defined patient cohorts which should not be solely based on LVEF.

\section{Conventional HF drugs in HFpEF}

\section{ACE inhibitors and AT1 antagonists}

Stimulation of AT1 receptors induces myocardial hypertrophy and fibrosis which can then lead to HF [54]. ACE inhibitors and angiotensin II receptor blockers (ARBs), which target the renin-angiotensin-aldosterone system (RAAS) pathway and inhibit the activation of AT1 receptors, reduce morbidity and mortality in patients with HFrEF [55-57]. In patients with $\mathrm{HFpEF}$, however, they have failed to improve clinical outcomes. In the I-PRESERVE trial, irbesartan did not reduce hospitalization rates for $\mathrm{CV}$ causes or all-cause mortality in patients with HF and LVEF of at least 45\% [58]. In the CHARM-PRESERVED study, candesartan reduced HF hospitalizations, but not CV death rates [59]. Perindopril has been shown to improve symptoms and exercise capacity but not morbidity or mortality in 850 elderly patients with a mean age of 76 years (PEP-CHF) [60]. The VALIDD study compared effects of valsartan to other antihypertensive agents in patients with evidence of diastolic dysfunction and hypertension [61]. In both groups, diastolic function improved after reduction of blood pressure, regardless of the antihypertensive treatment.

\section{Mineralocorticoid receptor antagonists}

Mineralocorticoid receptor antagonists (MRAs) prevent the maladaptive effects of aldosterone. Aldosterone mediates myocardial fibrosis [62], contributing to myocardial stiffness and filling abnormalities. The ALDO-DHF trial proved that spironolactone had a positive impact on diastolic function by reducing the $E / e^{\prime}$-ratio and decreased leftventricular (LV) hypertrophy and NT-proBNP levels [63]. Surprisingly, HF symptoms, exercise tolerance, and QOL have not been significantly affected by spironolactone. In the international, multicenter TOPCAT trial, spironolactone failed to significantly improve $\mathrm{CV}$ outcomes in 3445 HFpEF patients (LVEF $\geq 45 \%$ ) [52]. However, these findings might have been biased by regional differences. As compared to patients enrolled in the US, Canada, Brazil, and Argentina (the Americas), patients enrolled in Russia and Georgia exhibited markedly lower clinical event rates [64] and their concentrations of canrenone, an active metabolite of spironolactone, were much more likely to be undetectable, suggesting higher rates of patients' incompliance [65]. These aspects might explain why spironolactone was able to reduce risk of CV death and HF hospitalization in the American population, while this did not account for patients from Russia and Georgia [64]. Furthermore, treatment effects of spironolactone were influenced by LVEF and have reached significance at the lower end of the ejection fraction spectrum [66]. As a result, MRAs can now be considered to decrease hospitalizations in appropriately selected patients with HFpEF, according to the updated ACC/AHA/HFSA guidelines [67]. Critically, it needs to be outlined that the regional interaction analyses of the TOPCAT trial were post hoc, which can, therefore, only serve as hypothesis generating. In addition, the $p$ value for the treatment-by-region-interaction 
was not significant ( $p=0.12$ ) [64]. Moreover, when making recommendations about HF therapy based on regional interaction analyses, this should be equally applied to all HF drugs. For instance, beta-blockers have not shown any beneficial effects in the US population [68, 69], but are still recommended as an essential part of HF therapy in the USA. Furthermore, the potential mistakes in Russia and Georgia implied by the mentioned post hoc analyses were only possible because of the trial organization which wanted to save money by including Russians and Georgians.

In the future, new studies such as the German prospective SPIRIT-HF trial (2017-000697-11) and the large registry-randomized clinical trial SPIRRIT-HF (NCT02901184) will reevaluate therapy with spironolactone in HFpEF patients. In SPIRIT-HF, particular emphasis will lie on patient characterization and selection. Novel MRAs, such as nonsteroidal aldosterone antagonists, will also be evaluated [70,71].

\section{Beta-blockers}

High heart rate (HR) predicts poor outcome in patients with HFpEF and sinus rhythm, but does not apply for those in atrial fibrillation, as shown in a post hoc analysis of the I-PRESERVE trial [72]. These findings were supported by a sub-analysis of the CHART-2 study, in which elevated $\mathrm{HR}$ was associated with a higher CV mortality in $\mathrm{HFpEF}$ patients [73]. The MAGICC registry confirmed the prognostic association of HR in sinus rhythm, but not in atrial fibrillation in $2285 \mathrm{HFrEF}$ and $974 \mathrm{HFpEF}$ patients [74]. Thus, several studies investigated whether beta-blockers induce positive prognostic effects in patients with HFpEF by helping to reduce HR. In a pre-specified sub-analysis of the SENIORS trial, no significant differences were observed regarding the prognostic impact of nebivolol, a $\beta_{1}$-selective beta-blocker, in patients with impaired and preserved LV function (separation in this trial was LVEF > 35\%) [75]. In the ELANDD study, 6 month treatment with nebivolol led to a reduction in HR, while it had no effect on exercise capacity in terms of 6MWTD and peak oxygen consumption $\left(V_{2}\right)$ in $116 \mathrm{HFpEF}$ patients [76]. A large meta-analysis on the prognostic effects of beta-blockers in HFpEF showed a reduction in mortality by $21 \%$, but results were mainly influenced by findings from observational cohort studies [77]. In the pooled analysis of RCTs only, use of beta-blockers was associated with a reduced risk of mortality but without reaching statistical significance. The OPTIMIZE-HF registry, on the other hand, did not find a relevant prognostic effect of beta-blocker treatment in patients with HFpEF [17]. However, both the mentioned meta-analysis [77] and the OPTIMIZE-HF registry [17] did not assess potential differences in therapeutic efficacy between the different sub-classes of beta-blockers. Perhaps, beneficial effects may be present in selected sub-classes of beta-blockers which would need to be evaluated in further trials.

\section{Angiotensin receptor neprilysin inhibitor}

The angiotensin receptor neprilysin inhibitor LCZ696, combining the two acting agents valsartan and sacubitril, has revolutionized treatment of HFrEF. By inhibition of neprilysin, sacubitril increases ANP-, BNP- and CNP-plasma levels [33]. These peptides can then activate guanylyl cyclase resulting in formation of cGMP. Moreover, natriuretic peptides help to prevent myocardial fibrosis and to lower blood pressure due to vasodilation and increased diuresis [33]. As discussed above, prognosis of patients with HFpEF is affected by comorbidities such as diabetes. A post hoc analysis of the PARADIGM-HF trial revealed that sacubitril enhances glycemic control and reduces the necessity of insulin treatment in HFrEF patients [78]. This could be a further beneficial effect in patients with HFpEF, where diabetes is thought to trigger the disease. The PARAGON-HF trial evaluated therapy with LCZ696, and enrolled 4822 patients with HF and LVEF $\geq 45 \%$ [53]. As recently presented, LCZ696 failed to reduce the primary composite endpoint of total hospitalizations for HF and CV death. However, prespecified subgroup analyses suggested positive effects of LCZ696 in female patients and those with an LVEF at or below the median of all enrolled patients (45-57\%). Similarly, it was shown that treatment effects of LCZ696 are modified by LVEF, leading to the greatest benefits in patients with an LVEF of $<50 \%$ [79]. These findings are in accordance with several post hoc analyses of previous HF trials such as TOPCAT [66], CHARM [80], and a meta-analysis on beta-blocker effects in HF [81] that have shown positive treatment effects for patients exhibiting an LVEF of $40-49 \%$. Of note, these patients have to be categorized as $\mathrm{HFmEF}$ according to the ESC guidelines [7]. Moreover, a recent post hoc analysis of PARAGON-HF documented a significant treatment effect of LCZ696 in women, while there were no significant effects in men [82]. Furthermore, an important limitation of the PARAGON-HF trial consists in the missing exclusion of specific causes such as Amyloidosis and M. Fabry which are resistant to treatment with LCZ696.

In conclusion, results from the PARAGON-HF trial support the heterogeneity of the HFpEF syndrome as well as the importance of an individually tailored approach in $\mathrm{HFpEF}$ therapy. In this context, identifying specific causes of $\mathrm{HFpEF}$ by an aetiological work-up is of great importance. Moreover, LCZ696 might be associated with beneficial effects in female patients and those with a LVEF between 45-57\% which would include both HFmEF and HFpEF patients. 
This aspect may underline the limitations of subdividing HF phenotypes solely by LVEF. As the primary endpoint of PARAGON-HF was neutral, new prospective randomized studies in dedicated subgroups might scrutinize efficacy of LCZ696 in selected individuals.

\section{Ivabradine}

In a mouse model of HFpEF, established by diabetic mice $(\mathrm{db} / \mathrm{db}), \beta$-adrenergic receptor-independent reduction of HR with ivabradine, an inhibitor of the funny current, improved vascular stiffness, as well as systolic and diastolic function [83]. However, according to experimental data, this particular mouse model is not associated with marked structural remodeling of the heart [84]. In the EDIFY study, ivabradine reduced HR by $30 \%$, but failed to improve $E / e^{\prime}$ ratio, exercise tolerance, and NT-proBNP levels in HFpEF patients [85]. Apparently, the pathophysiological concept of prolonging diastole to improve diastolic function and prognosis cannot be applied to patients with HFpEF. A plausible explanation might be that chronotropic incompetence in HFpEF patients contributes to impaired exercise tolerance and ivabradine further reduces the exercise-induced increase in HR [86].

\section{Cardiac glycosides}

In the DIG trial, cardiac glycosides were able to decrease the risk for overall hospitalization and hospitalization due to worsening HF in patients with HFrEF and HFpEF (LVEF $>45 \%$ ) [58]. On the contrary, there have been no significant differences between digoxin and placebo regarding overall and CV mortality [59]. As a result, cardiac glycosides can be considered as a potential treatment to control tachyarrhythmia in patients with HFpEF.

\section{New options in treatment of HFpEF}

All main approaches regarding device and pharmacological therapy in HFpEF patients are highlighted in Fig. 2. Moreover, all current pharmacological and device trials in HFpEF patients are summarized in Tables 1, 2, 3 .

\section{Pharmacological}

Regulation of the NO-cGMP-PKG-axis Intervention in the nitrogen monoxide-cyclic guanosine monophosphateprotein kinase (NO-cGMP-PKG)-axis represents a new promising approach in treatment of HFpEF. Experimental data suggest that disturbance of this signal cascade poses a specific pathomechanism in $\mathrm{HFpEF}$, which promotes myocardial fibrosis, eventually leading to diastolic dysfunction
[87, 88]. Therefore, targeting the NO-cGMP-PKG pathway with phosphodiesterase-5 (PDE5) inhibitors, soluble guanylyl cyclase activators/stimulators, angiotensin receptor neprilysin inhibitor as well as NO-inducing drugs such as organic nitrates, inorganic nitrites/nitrates, $\beta_{3}$ adrenergic receptor $\left(\beta_{3}\right.$-AR)-selective agonists, or endothelial nitric oxide synthase (eNOS) enhancer have been studied (Fig. 3).

Enhancing NO bioavailability NO-donating drugs Direct NO donators, for instance organic nitrates (isosorbidenitrate), are not recommended in HFpEF patients. In the multicenter trial Neat-HFpEF on 110 patients with HFpEF, isosorbide mononitrate treatment even resulted in decreased activity levels [89]. One major disadvantage of organic nitrates is a strong vasodilatation, which can reduce systemic blood pressure dramatically. Inorganic nitrites, on the other hand, appear to improve ventricular performance with stress, especially by reducing pulmonary capillary wedge pressure (PCWP) and bear a much lower risk for reduction of systemic blood pressure [45]. Moreover, inorganic nitrites evolve their specific effects on hemodynamics precisely during exercise, presumably when patients benefit the most from symptom relief [90]. These effects also account for inorganic nitrates, the precursor to nitrite [91]. However, in the multicenter RCT INDIE-HFpEF, treatment with inhaled inorganic nitrite failed to increase exercise capacity, QOL, NYHA functional class, diastolic function $\left(E / e^{\prime}\right)$, and NT-proBNP levels [92]. As for now, results of the ongoing KNO3CKOUT-HFpEF trial, investigating effects of orally active potassium nitrate capsules, should be awaited, as they could differ from these previous findings (NCT02840799).

$\beta_{3} A R$-selective agonists Conventional beta-blockers mainly target $\beta_{1}$ - and $\beta_{2}$-adrenoreceptors ( $\beta_{1}$-AR/ $\beta_{2}$-AR), which can mediate maladaptive effects of prolonged catecholamine exposure including cardiac remodeling [93]. Moreover, a third subtype of $\beta$-adrenoreceptors, $\beta_{3}$-AR, has been identified in human hearts [94]. In contrast to $\beta_{1}$-AR and $\beta_{2}$-AR, these receptors prevent the myocardial hypertrophic response to neurohormonal stimulation [95]. As a result, the concept of stimulating $\beta_{3}$-AR with the selective agonist mirabegron as a therapeutic option in HFpEF is currently studied in two clinical trials (NCT02775539, NCT02599480).

Endothelial nitric oxide synthase (eNOS) activators Enhancing eNOS activity by the transcription amplifier AVE3085 results in increased production of $\mathrm{NO}$ and was shown to be associated with a significant improvement in diastolic function in a rat model [96]. However, clinical evaluation of the approach is still pending.

Potential limitations of enhancing NO bioavailability According to a recent mouse model, nitrosative stress needs to be acknowledged as one of the main drivers in HFpEF rather than the limited bioavailability of NO [97]. In this 


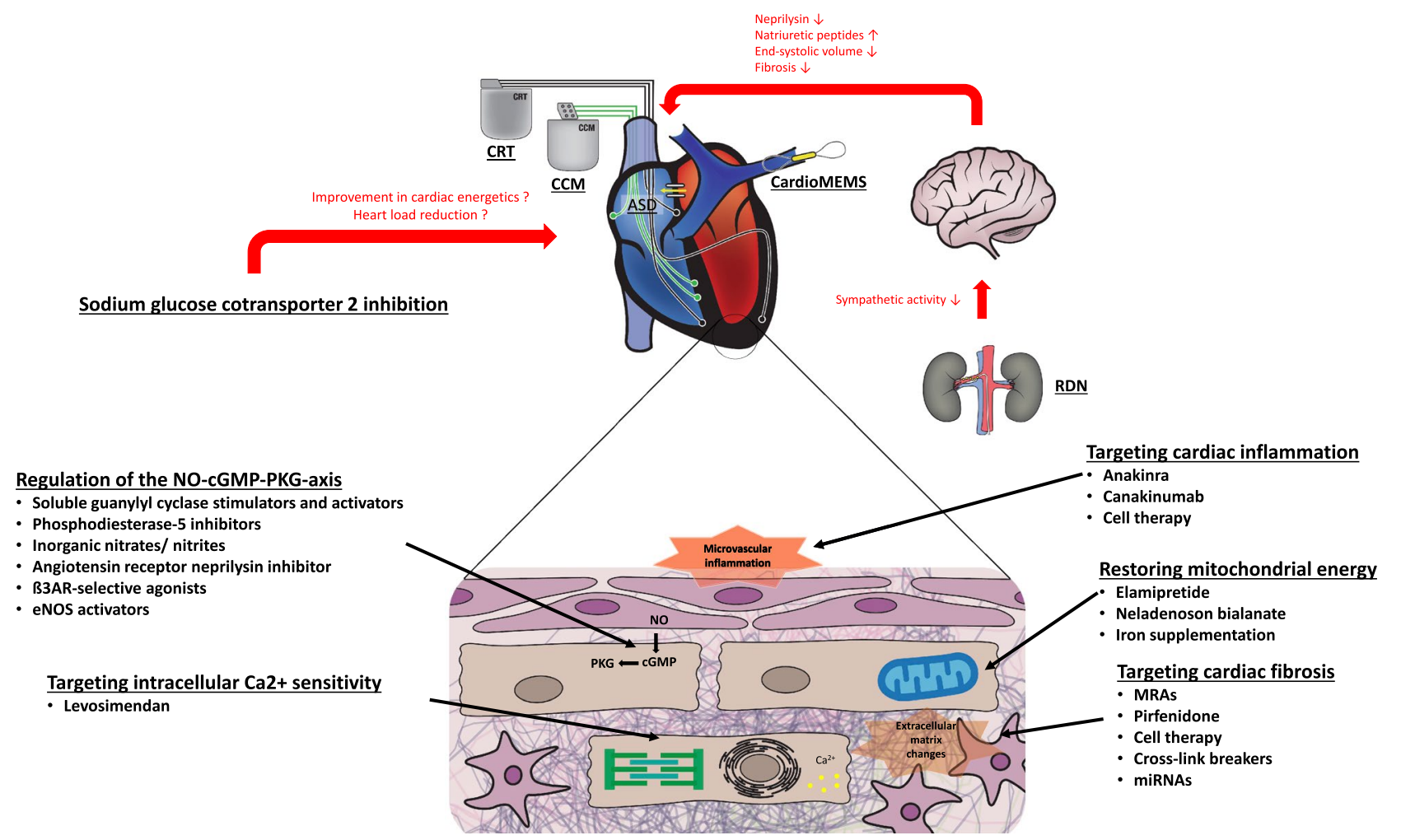

Fig. 2 Main approaches regarding device and pharmacological therapy in HFpEF patients. Renal denervation can lower sympathetic activity resulting in decreased neprilysin activation, end-systolic volumes, and cardiac fibrosis as well as increased levels of natriuretic peptides. By implantation of an atrial shunt device, left-atrial pressure can be reduced. Continuous measurement of pulmonary artery pressure with the CardioMEMS device helps to prevent cardiac decompensation. CRT devices target mechanical LV dyssynchrony in HFpEF patients. CCM devices aim to enhance myocardial contractility. Main pharmacological approaches in HFpEF comprise regulation of the NO-cGMP-PKG-axis, restoring mitochondrial energy, modu-

model, concomitant metabolic and hypertensive stress resulted in increased activity of inducible nitric oxide synthase (iNOS) which interfered with the inositol-requiring protein $1 \alpha$ (IRE1 $\alpha)-\mathrm{X}$-box-binding protein 1 (XBP1) pathway. These findings could explain why NO-inducing approaches have failed so far and could lead to new approaches targeting nitrosative stress, particularly inhibition of iNOS activity, in the future.

Phosphodiesterase-5 inhibitors Therapy with the PDE5 inhibitor sildenafil did not improve ${\mathrm{p} V \mathrm{O}_{2}}_{2}$ in HFpEF patients without evidence of pulmonary hypertension (PH) [98] and failed to significantly lower pulmonary artery pressure (PAP) and to improve hemodynamic parameters in patients suffering from HFpEF and resulting postcapillary $\mathrm{PH}$ [99]. However, use of sildenafil is an established therapy regimen in patients with precapillary $\mathrm{PH}$ and may be considered in certain forms of combined pre- and postcapillary $\mathrm{PH}(\mathrm{CpC}-$ $\mathrm{PH})$ when coexistence of pulmonary arterial hypertension lation of intracellular $\mathrm{Ca}^{2+}$ sensitivity as well as targeting cardiac inflammation and fibrosis. Furthermore, inhibition of the sodium glucose cotransporter-2 represents another important approach in $\mathrm{HFpEF}$ therapy, although the exact pathomechanisms are currently unknown. $A S D$ atrial shunt device, $C C M$ cardiac contractility modulation, $C R T$ cardiac resynchronization therapy, eNOS endothelial nitric oxide synthase, miRNA micro-RNA, MRA mineralocorticoid receptor antagonist, $N O-c G M P-P K G$ nitrogen monoxide-cyclic guanosine monophosphate-protein kinase, $R D N$ renal denervation. Figure modified according to Lam et al. [9] and Böhm et al. [135]

(PAH) and left heart disease is most likely. In accordance, it was shown that sildenafil can yield positive therapeutic effects in patients with $\mathrm{HFpEF}$ and severe forms of $\mathrm{CpC}-\mathrm{PH}$ [100]. Translation of these findings into general therapeutic recommendations needs to be evaluated in future studies (2010-020153-14).

Soluble guanylyl cyclase stimulators and activators Vericiguat and riociguat, primarily used to treat $\mathrm{PH}$, have been analyzed in HF patients in phase 2 clinical studies. As the SOCRATES-PRESERVED trial has shown, vericiguat improved QOL, but failed to reduce NT-proBNP levels or left-atrial volumes [101]. Currently, therapy with sGC stimulators and activators is further studied in various trials (NCT03153111, NCT03254485, NCT02744339, and NCT03547583). The RCT VITALITY-HFpEF (NCT03547583) for instance, will primarily evaluate treatment effects of vericiguat regarding physical function 
Table 1 Current pharmacological and device trials in HFpEF patients focusing on clinical outcomes

\begin{tabular}{|c|c|c|c|c|}
\hline Study name & Intervention & Study size & Primary endpoint & Identifier \\
\hline \multicolumn{5}{|c|}{ Sodium glucose cotransporter-2 inhibitors } \\
\hline EMPEROR-PRESERVED & Empagliflozin & 4126 & Change in CV death rate, time-to-first HF hospitalization & NCT03057951 \\
\hline DELIVER & Dapagliflozin & 4700 & $\begin{array}{l}\text { Change in } \mathrm{CV} \text { death rate, time-to-first HF hospitalization/first } \\
\text { urgent HF visit }\end{array}$ & NCT03619213 \\
\hline SOLOIST & Sotagliflozin & 4000 & Change in CV death rate, time-to-first HF hospitalization & NCT03521934 \\
\hline \multicolumn{5}{|c|}{ Mineralocorticoid receptor antagonists } \\
\hline SPIRRIT & Spironolactone & 3500 & Change in overall death rate & NCT02901184 \\
\hline SPIRIT-HF & Spironolactone & 1300 & $\begin{array}{l}\text { Change in CV death rate, number of recurrent HF hospitaliza- } \\
\text { tions }\end{array}$ & 2017-000697-11 \\
\hline \multicolumn{5}{|l|}{ Device therapy } \\
\hline GUIDE-HF & CardioMEMS & 3600 & $\begin{array}{l}\text { Change in all-cause mortality, total number of HF hospitaliza- } \\
\text { tions, iv diuretic visits }\end{array}$ & NCT03387813 \\
\hline REDUCE LAP-HF TRIAL II & IASD System II & 608 & $\begin{array}{l}\text { Change in incidence of and time-to-CV mortality or first non- } \\
\text { fatal, ischemic stroke, total rate per patient year of HF admis- } \\
\text { sions or healthcare facility visits for IV diuresis for HF and } \\
\text { time-to-first HF event, KCCQ }\end{array}$ & NCT03088033 \\
\hline
\end{tabular}

$C V$ cardiovascular, $H F$ heart failure, $I V$ intravenous, $K C C Q$ Kansas City Cardiomyopathy Questionnaire, $Q O L$ quality of life

assessed by the KCCQ PLS (Kansas City Cardiomyopathy Questionnaire Physical limitation score).

Anti-diabetic drugs Sodium-glucose cotransporter-2 inhibitors After empagliflozin led to a striking reduction of $\mathrm{CV}$ events in patients with type 2 diabetes at high $\mathrm{CV}$ risk in the EMPA-REG OUTCOME study [102], treatment with SGLT2 inhibitors was evaluated in HF patients with and without diabetes. As shown in the recent DAPA-HF trial, dapagliflozin resulted in a significant decrease of the primary composite endpoint of worsening HF or CV death in 4744 HFrEF patients, regardless of the presence or absence of diabetes [103]. Among the various pathomechanisms under discussion are the increase in renal function due to inhibition of the tubuloglomerular feedback system, the reduction in heart load as a result of the decrease in preload and afterload, and the improvement in cardiac energetics through an increase in ketones' supply [104, 105]. However, it is unknown whether these effects will account for HFpEF patients also. Finally, experimental data suggested that empagliflozin causes direct pleiotropic effects by improving diastolic stiffness, which are independent of diabetic conditions [106]. Currently, two large phase-III RCTs, including both HFpEF patients with and without diabetes, will investigate effects of the SGLT2 inhibitors empagliflozin (EMPEROR-PRESERVED; NCT03057951) and dapagliflozin (DELIVER; NCT03619213) on HF hospitalizations and CV mortality. In addition, the PRESERVED-HF trial with dapagliflozin (NCT03030235) and the EMPERIALPRESERVED trial with empagliflozin (NCT03448406) will primarily focus on treatment effects in regard to exercise capacity as measured by the 6MWD and NT-pro-BNP lev- els. According to a recent press release, empagliflozin did not have any significant effects on the primary endpoint in the EMPERIAL-PRESERVED trial [107].

Incretins Modulation of the incretin system includes mimicking glucagon-like peptide 1 (GLP-1) effects and inhibition of the GLP-1-degrading enzyme dipeptidyl peptidase-4 (DPP-IV) [108]. GLP-1, one of the major incretins, is released after food intake and stimulates insulin secretion from pancreatic $\beta$-cells [108]. The corresponding GLP-1 receptors are also found in cardiac myocytes and in certain regions of the brain [109]. In large cohorts of patients with type 2 diabetes at high CV risk, semaglutide and liraglutide, both GLP-1 mimetics, were able to significantly reduce mortality [110, 111]. Currently, there is only one small trial in HFpEF patients, which investigates effects of sitagliptin on hemodynamics as well as diastolic dysfunction and LV hypertrophy (NCT-2012-002,877-71).

Targeting cardiac fibrosis and inflammation Pirfenidone represents an anti-fibrotic drug which targets the TGF- $\beta$ signaling pathway and is mainly used in idiopathic pulmonary fibrosis [112]. By activation of myofibroblasts, TGF- $\beta$ can promote the production of fibronectin, proteoglycans and type I-III collagen. In mouse models with pressure-overload induced $\mathrm{HF}$, pirfenidone inhibits progression of contractile dysfunction and LV fibrosis after beginning of treatment [113]. The PIROUETTE-trial will investigate whether these effects account for HFpEF patients also (NCT02932566).

Cross-link breakers Cross-link breakers target advanced glycation endproducts (AGEs), which are formed by proteins and carbohydrates that underwent "cross-linking" with the extracellular matrix [114]. Production of AGEs 
Table 2 Current pharmacological and device trials in HFpEF patients focusing on biomarker levels, quality of life, and cognitive function

\begin{tabular}{|c|c|c|c|c|}
\hline Study name & Intervention & Study size & Primary endpoint & Identifier \\
\hline \multicolumn{5}{|c|}{ Soluble guanylyl cyclase stimulators and activators } \\
\hline SERENADE & Macitentan & 300 & Change in NT-proBNP levels & NCT03153111 \\
\hline VITALITY & Vericiguat & 735 & Change in QOL & NCT03547583 \\
\hline \multicolumn{5}{|l|}{ Inorganic nitrates/nitrites } \\
\hline PMED & Oral nitrate & 120 & Change in nitrate/nitrite level, microbiome & NCT02980068 \\
\hline \multicolumn{5}{|l|}{ Angiotensin receptor neprilysin inhibitor } \\
\hline PERSPECTIVE & LCZ696 & 520 & Change in cognitive function & NCT02884206 \\
\hline PARALLAX & LCZ696 & 2500 & Change in NT-proBNP levels & NCT03066804 \\
\hline \multicolumn{5}{|c|}{ Sodium glucose cotransporter-2 inhibitors } \\
\hline PRESERVED-HF & Dapagliflozin & 320 & Change in NT-proBNP levels & NCT03030235 \\
\hline ERADICATE-HF & Ertugliflozin & 36 & Change in proximal sodium reabsorption & NCT03416270 \\
\hline \multicolumn{5}{|l|}{ Restoring mitochondrial energy } \\
\hline $\begin{array}{l}\text { Elamipretide in patients hospitalized } \\
\text { with congestion due to HF }\end{array}$ & Elamipretide & 300 & Change in NT-pro-BNP levels & NCT02914665 \\
\hline \multicolumn{5}{|l|}{ Device therapy } \\
\hline CCM-HFpEF & $\mathrm{CCM}$ & 50 & Change in QOL & NCT03240237 \\
\hline
\end{tabular}

$Q O L$ quality of life, NT-pro-BNP N-terminal-pro hormone B-type natriuretic peptide

is triggered by oxidative stress and is associated with impaired diastolic function [115]. In a small cohort of 23 patients, treatment with the cross-link breaker Alagebrium chloride decreased LV mass and improved LV diastolic filling and QOL [116]. A similar concept which aims to interfere with the formation of AGEs is the antibodymediated inhibition of the enzyme Lysyl oxidase-like 2 (Lox12). Loxl2 can contribute to the cross-linking of collagen, eventually leading to interstitial fibrosis and diastolic dysfunction [115]. In mouse models, inhibition of Loxl2 improved systolic and diastolic function [117]. Clinical evaluations of Lox12-inhibition and new cross-linking strategies have to be awaited.

Micro-RNAs Micro-RNAs (miRNAs) are small non-coding RNA molecules which can interfere with gene expression on a post-transcriptional level by binding to messengerRNA [118]. There is a variety of different miRNAs, and their profiles typically differ between patients with $\mathrm{HFpEF}$ and HFrEF [119, 120]. For instance, inhibition of miRNA21 prevented development of HFpEF, which was associated with reduced expression of the anti-apoptotic gene Bcl-2 in rats [121]. Therefore, targeting miRNAs and trying to interfere with their effects might introduce a new potential therapy regimen in the future. However, the knowledge about the mechanisms of action is incompletely resolved and needs to be understood better before these concepts will be tested in clinical trials.

Cytokine inhibitors Derived from the pathophysiological model of systemic inflammation being one of the main mediators in the development of HFpEF, cytokine inhibitors have been tested as therapeutic options. In the D-HART2 trial [122], interleukin-1 (IL-1) blockade with anakinra was not able to improve aerobic exercise capacity in terms of $V \mathrm{O}_{2}$ and ventilatory efficiency. However, in a sub-analysis of the large RCT CANTOS [123] including patients with previous myocardial infarction, increased high-sensitivity C-reactive protein levels and history of HF, therapy with canakinumab, a monoclonal antibody targeting IL-1B, significantly decreased risk of HF hospitalizations as well as the composite of HF hospitalization or HF-related mortality [124].

Cell therapy Cell therapy targets myocardial inflammation and myocardial fibrosis in HFpEF. In rat models, application of cardiosphere-derived cells (CDCs) decreased LV fibrosis and inflammatory infiltrates achieving normalization of LV relaxation and diastolic pressures and, therefore, led to an improvement in survival [125]. The safety of this concept will be studied in the ongoing REGRESS-HFpEF-trial (NCT02941705). Furthermore, a pilot study on 14 patients with HFpEF showed that treatment with $\mathrm{CD} 34^{+}$cells, collected by apheresis after G-CSF stimulation, resulted in an enhancement in diastolic function $\left(E / e^{\prime}\right)$, and decreased NTproBNP levels [126]. CD34 ${ }^{+}$cell therapy in patients with HFpEF is currently under further evaluation in the CELLpEF-trial (NCT02923609). However, cell therapy has been evaluated as a promising therapy for $\mathrm{CV}$ diseases in numerous past trials without delivering consistent and convincing results. Questions about optimal cell type, dose, and delivery route are still inadequately answered [127].

Restoring mitochondrial energy Szeto-Schiller peptides "Szeto-Schiller peptides (SS peptides)" belong to a new 
Table 3 Current pharmacological and device trials in HFpEF patients focusing on echo/hemodynamic parameters

\begin{tabular}{|c|c|c|c|c|}
\hline Study name & Intervention & Study size & Primary endpoint & Identifier \\
\hline \multicolumn{5}{|c|}{ Soluble guanylyl cyclase stimulators and activators } \\
\hline CAPACITY-HF & IW 1973 & 184 & Change in peak $V \mathrm{O}_{2}$ & NCT03254485 \\
\hline DYNAMIC & Riociguat & 114 & Change in $\mathrm{CO}$ & NCT02744339 \\
\hline \multicolumn{5}{|c|}{ Phosphodiesterase-5 inhibitors } \\
\hline Sildenafil in HFPEF and PH & Sildenafil & 52 & Change in PAP, CO & 2010-020153-14 \\
\hline \multicolumn{5}{|l|}{ Inorganic nitrates/nitrites } \\
\hline INABLE & Oral inorganic nitrite & 100 & Change in peak $V \mathrm{O}_{2}$ & NCT0271312 \\
\hline KNO3CK OUT HFPEF & Oral potassium nitrate & 76 & Change in QOL, muscle blood flow, SVR reserve & NCT0284079 \\
\hline PH-HFPEF & Oral nitrite & 26 & Change in PAP at exercise & NCT03015402 \\
\hline $\mathrm{ONOH}$ & Oral nitrite & 18 & Change in peak $\mathrm{VO}_{2}$ & NCT02918552 \\
\hline Neo40 & Oral nitrate supplement & 25 & Change in exercise capacity, $E / e^{\prime}, \mathrm{RVSP}$ & NCT03289481 \\
\hline \multicolumn{5}{|l|}{ 3AR-selective agonists } \\
\hline BETA3_LVH & Mirabegron & 297 & Change in LVMI, $E / e^{\prime}$ & NCT02599480 \\
\hline SPHERE-HF & Mirabegron & 80 & Change in PVR & NCT02775539 \\
\hline \multicolumn{5}{|c|}{ Sodium glucose cotransporter-2 inhibitors } \\
\hline EMPERIAL-PRESERVED & Empagliflozin & 300 & Change in 6MWD & NCT03448406 \\
\hline \multicolumn{5}{|l|}{ Other antidiabetic drugs } \\
\hline Metformin for PH + HFPEF & Metformin & 32 & Change in PAP at exercise & NCT03629340 \\
\hline cGETS & Sitagliptin & 25 & $\begin{array}{l}\text { Change in hemodynamics during Dobutamine } \\
\text { stress test, diastolic dysfunction, LV hypertrophy }\end{array}$ & 2012-002877-71 \\
\hline \multicolumn{5}{|l|}{ Pirfenidone } \\
\hline PIROUETTE & Pirfenidone & 200 & Change in ECV & NCT02932566 \\
\hline \multicolumn{5}{|l|}{ Cell therapy } \\
\hline CELL-pEF & $\mathrm{CD}_{3}{ }^{+}$cell therapy & 30 & Change in $E / e^{\prime}$ & NCT02923609 \\
\hline \multicolumn{5}{|c|}{ Restoring mitochondrial energy } \\
\hline $\begin{array}{l}\text { Elamipretide in subjects with } \\
\text { stable HFpEF }\end{array}$ & Elamipretide & 46 & Change in $E / e^{\prime}$ & NCT02814097 \\
\hline FAIR-HFpEF & Ferric carboxymaltose & $\begin{array}{l}200 \text { Change } \\
\text { in 6MWD }\end{array}$ & NCT03074591 & \\
\hline PREFER-HF & Ferric carboxymaltose & 72 & Change in 6MWD & NCT03833336 \\
\hline \multicolumn{5}{|c|}{ Targeting intracellular $\mathrm{Ca}^{2+}$ sensitivity } \\
\hline HELP & Levosimendan & 36 & Change in PCWP at exercise & NCT03541603 \\
\hline \multicolumn{5}{|l|}{ Prostaglandin derivatives } \\
\hline ILO-HOPE & Iloprost & 34 & Change in PCWP after exercise & NCT03620526 \\
\hline SOUTHPAW & Treprostinil & 310 & Change in 6MWD & NCT03037580 \\
\hline \multicolumn{5}{|l|}{ Device therapy } \\
\hline RAPID-HF & CRT & 30 & Change in $\mathrm{VO}_{2}$ at VAT & NCT02145351 \\
\hline PREFECTUS & CRT & 10 & Change in systolic and diastolic reserve index & NCT03338374 \\
\hline
\end{tabular}

$C O$ cardiac output, $E C V$ extracellular volume fraction, $L V M I$ left-ventricular mass index, $P A P$ pulmonary arterial pressure, $P C W P$ pulmonary capillary wedge pressure, $P V R$ pulmonary vascular resistance, $Q O L$ quality of life, $R V S P$ right-ventricular systolic pressure, $S V R$ systemic vascular resistance, $V A T$ ventilatory anaerobic threshold, $V_{2}$ oxygen consumption

class of antioxidant peptides that bind to the cardiolipin, an important phospholipid in the inner mitochondrial membrane. SS peptides protect cardiolipin from oxidation and, thereby, prevent the damage of oxidative stress to mitochondria, maintaining ATP production and reducing further oxidative stress [128]. The most prominent and first compound is elamipretide (MTP-131, SS31) which has been subject of clinical studies after experimental data delivered encourag- ing results [129]. In the EMBRACE-STEMI study, elamipretide was safe, but failed to reduce infarct size as assessed by CK-MB levels in patients during/after ST-elevation myocardial infarction and successful percutaneous coronary intervention [130]. In patients with HFpEF, elamipretide reduced left-ventricular end-diastolic volumes compared to placebo after $4 \mathrm{~h}$ of infusion [131]. Currently, two phase II clinical trials test the clinical efficacy of elamipretide 


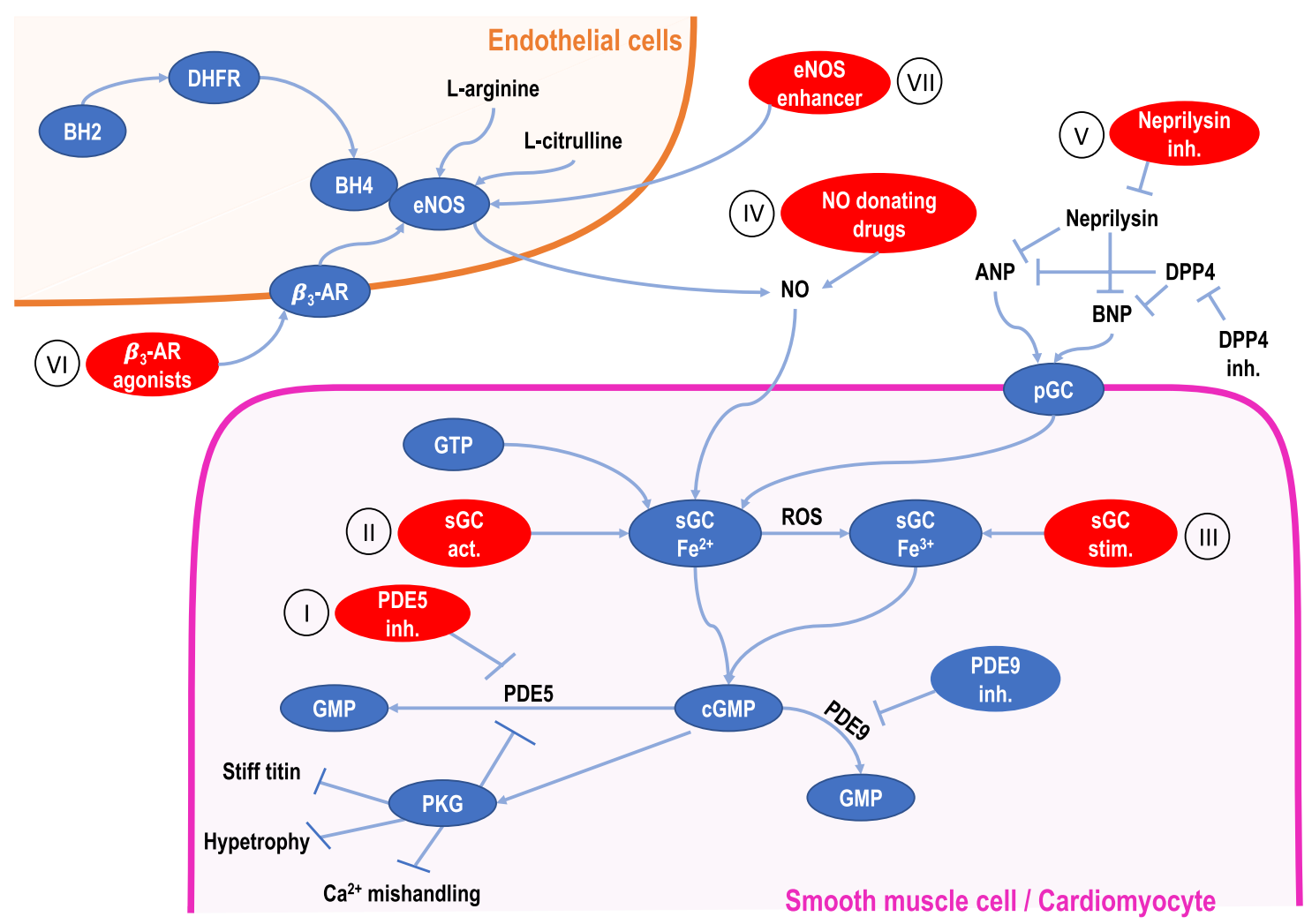

Fig. 3 Current pharmacological approaches regarding regulation of the NO-cGMP-PGK-axis. Drugs targeting the NO-cGMP-PGKaxis aim to promote formation of cGMP, which increases PKG activity. PKG plays a pivotal role in titin phosphorylation contributing to reduction in cardiomyocyte passive stiffness [136]. PKG phosphorylation targets can also lower levels of key transcription factors and sarcomeric proteins mediating LV hypertrophy, diastolic relaxation, LV stiffness, and vasorelaxation. Furthermore, PKG-dependent phosphorylation of phospholamban can improve sarcoplasmic reticulum $\mathrm{Ca}^{2+}$-ATPase (SERCA) activity [137] and, therefore, helps to prevent $\mathrm{Ca}^{2+}$ mishandling. PDE5 inhibitors (I) protect cGMP from degradation by PDE5. While sGC activators (II) bind to nonoxidized sGC $\left(\mathrm{Fe}^{2+}\right)$, sGC stimulators (III) target oxidized sGC $\left(\mathrm{Fe}^{3+}\right)$. Neprilysin inhibitors $(\mathrm{V})$ prevent degradation of natriuretic peptides, particu-

in patients with acute or chronic HFpEF (NCT02814097, NCT02914665).

Adenosine A1 receptor agonists The partial adenosine A1 receptor agonist Neladenoson bialanate is thought to yield several beneficial effects in the heart and also in the skeletal muscle. These compromise improvement in mitochondrial function and energy substrate utilization, enhanced SERCA2a activity, reversion of ventricular remodeling, and providing anti-ischemic properties [132]. In the PANACHEtrial (NCT03098979), treatment with Neladenoson bialanate failed to significantly affect the primary endpoint "change in 6MWD" in HFpEF patients [133].

Targeting intracellular calcium homoeostasis and calcium sensitivity Levosimendan According to ESC guidelines, larly ANP and BNP, which can then bind to pGC. NO-donating drugs (IV) enhance bioavailability of NO, leading to stimulation of sGC. By binding to $\beta 3$-AR on endothelial cells, $\beta 3$-AR-selective agonists (VI) promote activity of eNOS, resulting in production of NO. The eNOS enhancer AVE3085 (VII) directly affects eNOS. ANP atrial natriuretic peptide, $\beta 3-A R \quad \beta 3$ adrenergic receptor, $B H 2$ dihydrobiopterin, $B H 4$ tetrahydrobiopterin, $B N P$ B-type natriuretic peptide, $D H F R$ dihydrofolate reductase, DPP4 dipeptidyl peptidase-4, eNOS endothelial nitric oxide synthase, GTP guanosine triphosphate, $P D E$ phosphodiesterase, $p G C$ particulate guanylate cyclase, $P K G$ protein kinase $\mathrm{G}, R O S$ reactive oxygen species, $s G C$ soluble guanylate cyclase. Figure modified according to Papp et al. [138] and Kovacs et al. [139]

levosimendan, a calcium sensitizer and PDE3 inhibitor with vasodilative properties [104], can be considered in patients with acute HF and severe reduction of cardiac output (CO), resulting in compromised vital organ perfusion [7]. The positive inotropic effect of levosimendan is the result of a combined effect on troponin $\mathrm{C}$ (sensitization to calcium binding) and PDE3-inhibition, increasing cAMP and calcium [104]. Moreover, infusions of levosimendan decreased PAP, NTproBNP levels, and inflammatory status by altering the ratio of interleukin- 6 to interleukin-10 as well as improved diastolic function and right-ventricular systolic function in 54 patients with advanced HF due to left heart failure (NYHA III-IV, LVEF < 35\%) [134]. Thus, the current RCT HELP will investigate the effects of levosimendan in $36 \mathrm{HFpEF}$ 
patients with diagnosed group $2 \mathrm{PH}$ (PH due to left heart disease) (NCT03541603).

Prostacyclin analogues In patients with group $2 \mathrm{PH}$ and $\mathrm{HFpEF}$, administration of inhaled iloprost led to an acute reduction of PAP and pulmonary vascular resistance (PVR) during right heart catheterization [135]. The two RCTs ILOHOPE and SOUTHPAW will help to further evaluate treatment effects of prostacyclin analogues in patients suffering from HFpEF (NCT03037580, NCT03620526).

\section{Device therapies}

Home monitoring Fluid overload in patients with HFpEF can rapidly reduce QOL by causing dyspnea and peripheral edema or even lead to hospitalization due to cardiac decompensation. Since hospitalization for HF is associated with a higher mortality risk [136], monitoring of HF patients to avoid symptom deterioration or hospitalization has come into focus as one important part of the therapy. In 2007, the first studies introduced monitoring of HF patients with a new radiofrequency-based wireless pressure sensor (CardioMEMS device), implanted into the pulmonary artery and which continuously monitors pulmonary artery pressure $[137,138]$. In the subsequent CHAMPION trial, usage of CardioMEMS in NYHA III patients with HFpEF and HFrEF was able to reduce HF-related hospitalizations [139]. The 1 year outcome results of the CardioMEMS Postapproval study confirmed efficacy of home monitoring in $1200 \mathrm{HF}$ patients [140]. After implantation of the CardioMEMS device, event rate of HF hospitalization/all-cause death per patient year was reduced by $44 \%$. The large multicenter RCT GUIDE-HF will try to reproduce these results in 3600 symptomatic HF patients (NCT03387813).

Atrial shunt device The idea of creating artificial left-right shunts to reduce left-atrial pressure originates from a publication from the early twentieth century. The so-called Lutembacher syndrome was used to describe the finding that patients with an untreated mitral stenosis and resulting increase in left-atrial pressure benefit from a concomitant atrial septal defect [141]. In a pilot trial, which included 11 patients with an LVEF of at least $45 \%$, implantation of an atrial shunt device led to a significant reduction of LV-filling pressures after 30 days [142]. Remarkably, no patient developed PH after the procedure. Analogously, the REDUCE LAP-HF I trial on a total of 64 patients recorded a reduction in left-atrial pressure during exercise with improvement in functional capacity and QOL after shunt implantation [143]. The latest 1-year results of REDUCE LAP-HF I showed no significant differences in major adverse cardiac, cerebrovascular, or renal events compared to patients who underwent sham procedure, suggesting this method to be safe [144]. In the future, the REDUCE-LAP-HF II trial, which focuses on clinical outcomes, will hopefully take up from these positive results (NCT03088033).

Cardiac resynchronization therapy (CRT) In HFpEF patients, LV mechanical dyssynchrony has been suggested to contribute to an impairment of longitudinal systolic and diastolic LV function and to be associated with higher LV-filling pressures and worse clinical status in terms of NYHA functional class [145]. On the other hand, a post hoc analysis of the TOPCAT trial has shown that LV mechanical dyssynchrony is not associated with outcomes of HFpEF patients [146]. Targeting LV dyssynchrony by implantation of a CRT device is currently subject of ongoing studies, which will help to better understand its relevance for the therapy of HFpEF patients (NCT03338374, NCT02145351).

Cardiac contractility modulation (CCM) CCM aims to trigger molecular remodeling by delivering electrical signals into the septum during the refractory period and has been associated with numerous beneficial effects in chronic HF such as increased titin and troponin phosphorylation, and reduced expression of proteins that mark cardiac fibrosis [147]. In two female patients, CCM has been shown to improve clinical status and echocardiographic parameters early after initiation of CCM therapy [148]. The CCMHFpEF trial will study the effects of CCM on QOL in patients with HFpEF (NCT03240237).

Renal denervation Renal denervation (RDN), a catheterbased, radiofrequency ablation of the renal sympathetic nerves, has been shown to effectively lower both systolic and diastolic blood pressure [149, 150]. Furthermore, reduction of cardiac sympathetic activity occurs independently from blood pressure reduction, suggesting direct effects on the heart [151]. As a consequence, RDN reduced LV mass and improved diastolic function [152154]. However, the underpowered RDT-PEF trial including 25 patients with HFpEF did not confirm a beneficial effect of RDN on diastolic parameters and QOL [155]. Further investigations are needed to clarify the therapeutic value of RDN in HFpEF.

\section{What is left?}

Fluid overload can cause preload increase and as a result cardiac decompensation. Patients may suffer from peripheral edema and signs of congestion such as dyspnea. Therefore, diuretics, which are established drugs to treat fluid overload and signs of congestion, are a cornerstone in the symptomatic therapy of HFpEF [7]. Treatment with ACE 
inhibitors or ARBs did not result in further improvement regarding QOL, exercise capacity, or myocardial function after initiation of optimal diuretic therapy [156]. However, overtreatment should be avoided as it can cause excessive preload reduction and reduction in filling pressures, which stiff hearts may depend on [33].

\section{Summary and perspective}

The 2016 ESC/HFA guidelines [7] acknowledge the fact that no treatment has been convincingly shown to reduce morbidity or mortality in HFpEF patients. Since then, further efforts have been made to improve understanding and treatment of the HFpEF syndrome. However, diagnosis of HFpEF remains controversial and there is growing appreciation that HF, and particular HFpEF, represents a heterogeneous syndrome with various phenotypes and comorbidities which are hardly to differentiate solely by LVEF and might benefit from individually tailored approaches $[9,157]$. These aspects are also supported by the results of the recently presented PARAGON-HF trial [53], which failed to show beneficial treatment effects of LCZ696 in HFpEF patients, but has been associated with positive effects in female patients and patients with an LVEF between 45-57\%. In the future, prospective randomized studies should be conducted in welldefined, dedicated subgroups which take various information (clinical characteristics, biomarker levels, and imaging modalities) into account. In this context, new diagnostic techniques such as novel imaging strategies may help to differentiate the etiologies of HFpEF, to identify situations with specific treatment options, and to stratify available treatments. Among the various therapeutic approaches that have been introduced lately, therapy with SGLT2 inhibitors promises the greatest potential for the future, as it has just been proven efficient in HFrEF patients and is currently studied in two large RCT. In addition, innovative device therapies, in particular creating artificial left-right shunts by implantation of an atrial shunt device, pose exciting options for the future, but need to be proven safe first. As for now, treatment of HFpEF is limited to symptom relief, which effectively improves QOL. Therefore, further research is desperately needed, to manage the challenging syndrome HFpEF.

Acknowledgements Open Access funding provided by Projekt DEAL.

Funding This work has not been funded.

\section{Compliance with ethical standards}

Conflict of interest JW, IK, ChU, ChM, SS, ChW, and MB are supported by the Deutsche Forschungsgemeinschaft (SFB TTR 219, S-01 (JW, IK, MB), M-02 (SS, MB), M-04 (ChM), and M-06 (ChW). ChM is further supported by DFG SFB 894 and Ma 2528/7-1 and the German Ministry for Education and Science (BMBF, 01EO1504). IK received speaker honoraria from/ is a consultant to Servier, Astra, Boehringer Ingelheim, Novartis, Pfizer, Vifor, and Bayer. ChM received speaker honoraria from Bayer, Boehringer Ingelheim, Servier, Novartis, Pfizer, and Berlin Chemie, and is a consultant to Servier. SDA has received research support from Vifor International \& Abbott Vascular, and fees for consultancy and/or speaking from Astra Zeneca, Bayer, Boehringer Ingelheim, Respicardia, Impulse Dynamics, Janssen, Novartis, Servier, and Vifor International. MB received speaker honoraria from/ is a consultant to Servier, Astra, Boehringer Ingelheim, Medtronic, and Vifor. There are no further relationships that could be construed as a conflict of interest.

Open Access This article is licensed under a Creative Commons Attribution 4.0 International License, which permits use, sharing, adaptation, distribution and reproduction in any medium or format, as long as you give appropriate credit to the original author(s) and the source, provide a link to the Creative Commons licence, and indicate if changes were made. The images or other third party material in this article are included in the article's Creative Commons licence, unless indicated otherwise in a credit line to the material. If material is not included in the article's Creative Commons licence and your intended use is not permitted by statutory regulation or exceeds the permitted use, you will need to obtain permission directly from the copyright holder. To view a copy of this licence, visit http://creativecommons.org/licenses/by/4.0/.

\section{References}

1. Borlaug BA, Melenovsky V, Russell SD, Kessler K, Pacak K, Becker LC, Kass DA (2006) Impaired chronotropic and vasodilator reserves limit exercise capacity in patients with heart failure and a preserved ejection fraction. Circulation 114(20):2138-2147

2. Dougherty AH, Naccarelli GV, Gray EL, Hicks CH, Goldstein RA (1984) Congestive heart failure with normal systolic function. Am J Cardiol 54(7):778-782

3. Topol EJ, Traill TA, Fortuin NJ (1985) Hypertensive hypertrophic cardiomyopathy of the elderly. N Engl J Med 312(5):277-283

4. Ferrari R, Böhm M, Cleland JGF, Paulus WJS, Pieske B, Rapezzi C, Tavazzi L (2015) Heart failure with preserved ejection fraction: uncertainties and dilemmas. Eur J Heart Fail 17(7):665-671

5. Bursi F, Weston SA, Redfield MM, Jacobsen SJ, Pakhomov S, Nkomo VT, Meverden RA, Roger VL (2006) Systolic and diastolic heart failure in the community. JAMA 296(18):2209-2216

6. Kraigher-Krainer E, Shah AM, Gupta DK, Santos A, Claggett B, Pieske B, Zile MR, Voors AA, Lefkowitz MP, Packer M, McMurray JJV, Solomon SD (2014) Impaired systolic function by strain imaging in heart failure with preserved ejection fraction. J Am Coll Cardiol 63(5):447-456

7. Ponikowski P, Voors AA, Anker SD, Bueno H, Cleland JGF, Coats AJS, Falk V, Gonzalez-Juanatey JR, Harjola VP, Jankowska EA, Jessup M, Linde C, Nihoyannopoulos P, Parissis JT, Pieske B, Riley JP, Rosano GMC, Ruilope LM, Ruschitzka F et al (2200m) 2016 ESC Guidelines for the diagnosis and treatment of acute and chronic heart failure. Eur Heart J 37(27):2129-2200m

8. Pieske B, Tschöpe C, de Boer RA, Fraser AG, Anker SD, Donal E, Edelmann F, Fu M, Guazzi M, Lam CSP, Lancellotti P, Melenovsky V, Morris DA, Nagel E, Pieske-Kraigher E, Ponikowski P, Solomon SD, Vasan RS, Rutten FH et al (2019) How to diagnose heart failure with preserved ejection fraction: the HFAPEFF diagnostic algorithm: a consensus recommendation from the Heart Failure Association (HFA) of the European Society of Cardiology (ESC). Eur Heart J 40(40):3297-3317 
9. Triposkiadis F, Butler J, Abboud FM, Armstrong PW, Adamopoulos S, Atherton JJ, Backs J, Bauersachs J, Burkhoff D, Bonow RO, Chopra VK, de Boer RA, de Windt L, Hamdani N, Hasenfuss G, Heymans S, Hulot J-S, Konstam M, Lee RT et al (2019) The continuous heart failure spectrum: moving beyond an ejection fraction classification. Eur Heart J 40(26):2155-2163

10. Reddy YNV, Carter RE, Obokata M, Redfield MM, Borlaug BA (2018) A simple, evidence-based approach to help guide diagnosis of heart failure with preserved ejection fraction. Circulation 138(9):861-870

11. Kreusser MM, Volz MJ, Knop B, Ehlermann P, Schmack B, Ruhparwar A, Hegenbart U, Schonland SO, Katus HA, Raake PW (2019) A novel risk score to predict survival in advanced heart failure due to cardiac amyloidosis. Clin Res Cardiol. https://doi. org/10.1007/s00392-019-01559-y

12. Gillmore JD, Damy T, Fontana M, Hutchinson M, Lachmann HJ, Martinez-Naharro A, Quarta CC, Rezk T, Whelan CJ, GonzalezLopez E, Lane T, Gilbertson JA, Rowczenio D, Petrie A, Hawkins PN (2018) A new staging system for cardiac transthyretin amyloidosis. Eur Heart J 39(30):2799-2806

13. Grogan M, Scott CG, Kyle RA, Zeldenrust SR, Gertz MA, Lin G, Klarich KW, Miller WL, Maleszewski JJ, Dispenzieri A (2016) Natural history of wild-type transthyretin cardiac amyloidosis and risk stratification using a novel staging system. J Am Coll Cardiol 68(10):1014-1020

14. Maurer MS, Schwartz JH, Gundapaneni B, Elliott PM, Merlini G, Waddington-Cruz M, Kristen AV, Grogan M, Witteles R, Damy T, Drachman BM, Shah SJ, Hanna M, Judge DP, Barsdorf AI, Huber P, Patterson TA, Riley S, Schumacher J et al (2018) Tafamidis treatment for patients with transthyretin amyloid cardiomyopathy. N Engl J Med 379(11):1007-1016

15. Frantz S, Falcao-Pires I, Balligand J-L, Bauersachs J, Brutsaert D, Ciccarelli M, Dawson D, de Windt LJ, Giacca M, Hamdani N, Hilfiker-Kleiner D, Hirsch E, Leite-Moreira A, Mayr M, Thum T, Tocchetti CG, van der Velden J, Varricchi G, Heymans S (2018) The innate immune system in chronic cardiomyopathy: a European Society of Cardiology (ESC) scientific statement from the Working Group on Myocardial Function of the ESC. Eur J Heart Fail 20(3):445-459

16. Lam CSP, Donal E, Kraigher-Krainer E, Vasan RS (2011) Epidemiology and clinical course of heart failure with preserved ejection fraction. Eur J Heart Fail 13(1):18-28

17. Fonarow GC, Stough WG, Abraham WT, Albert NM, Gheorghiade M, Greenberg BH, O'Connor CM, Sun JL, Yancy CW, Young JB (2007) Characteristics, treatments, and outcomes of patients with preserved systolic function hospitalized for heart failure: a report from the OPTIMIZE-HF Registry. J Am Coll Cardiol 50(8):768-777

18. Paulus WJ, Tschöpe C (2013) A novel paradigm for heart failure with preserved ejection fraction: comorbidities drive myocardial dysfunction and remodeling through coronary microvascular endothelial inflammation. J Am Coll Cardiol 62(4):263-271

19. Gevaert AB, Boen JRA, Segers VF, Van Craenenbroeck EM (2019) Heart failure with preserved ejection fraction: a review of cardiac and noncardiac pathophysiology. Front Physiol 10:638

20. Borbely A, van der Velden J, Papp Z, Bronzwaer JGF, Edes I, Stienen GJM, Paulus WJ (2005) Cardiomyocyte stiffness in diastolic heart failure. Circulation 111(6):774-781

21. Zile MR, Baicu CF, Ikonomidis JS, Stroud RE, Nietert PJ, Bradshaw AD, Slater R, Palmer BM, Van Buren P, Meyer M, Redfield MM, Bull DA, Granzier HL, LeWinter MM (2015) Myocardial stiffness in patients with heart failure and a preserved ejection fraction: contributions of collagen and titin. Circulation 131(14):1247-1259
22. Krüger M, Kotter S, Grutzner A, Lang P, Andresen C, Redfield MM, Butt E, dos Remedios CG, Linke WA (2009) Protein kinase $\mathrm{G}$ modulates human myocardial passive stiffness by phosphorylation of the titin springs. Circ Res 104(1):87-94

23. Creemers EE, Pinto YM (2011) Molecular mechanisms that control interstitial fibrosis in the pressure-overloaded heart. Cardiovasc Res 89(2):265-272

24. Kakkar R, Lee RT (2010) Intramyocardial fibroblast myocyte communication. Circ Res 106(1):47-57

25. van Heerebeek L, Franssen CPM, Hamdani N, Verheugt FWA, Somsen GA, Paulus WJ (2012) Molecular and cellular basis for diastolic dysfunction. Curr Heart Fail Rep 9(4):293-302

26. de Boer RA, Edelmann F, Cohen-Solal A, Mamas MA, Maisel A, Pieske B (2013) Galectin-3 in heart failure with preserved ejection fraction. Eur J Heart Fail 15(10):1095-1101

27. Zhang X, Karunathilaka N, Senanayake S, Subramaniam VN, Chan W, Kostner K, Fraser J, Atherton JJ, Punyadeera C (2019) The potential prognostic utility of salivary galectin-3 concentrations in heart failure. Clin Res Cardiol. https://doi.org/10.1007/ s00392-019-01557-0

28. de Boer RA, De Keulenaer G, Bauersachs J, Brutsaert D, Cleland JG, Diez J, Du X-J, Ford P, Heinzel FR, Lipson KE, McDonagh T, Lopez-Andres N, Lunde IG, Lyon AR, Pollesello P, Prasad SK, Tocchetti CG, Mayr M, Sluijter JPG et al (2019) Towards better definition, quantification and treatment of fibrosis in heart failure. A scientific roadmap by the Committee of Translational Research of the Heart Failure Association (HFA) of the European Society of Cardiology. Eur J Heart Fail. 21(3):272-285

29. Lam CSP, Voors AA, de Boer RA, Solomon SD, van Veldhuisen DJ (2018) Heart failure with preserved ejection fraction: from mechanisms to therapies. Eur Heart J 39(30):2780-2792

30. Dunlay SM, Roger VL, Redfield MM (2017) Epidemiology of heart failure with preserved ejection fraction. Nat Rev Cardiol 14(10):591-602

31. Ergatoudes C, Schaufelberger M, Andersson B, Pivodic A, Dahlstrom U, Fu M (2019) Non-cardiac comorbidities and mortality in patients with heart failure with reduced vs. preserved ejection fraction: a study using the Swedish Heart Failure Registry. Clin Res Cardiol. https://doi.org/10.1007/s00392-019-01430-0

32. Riedel O, Ohlmeier C, Enders D, Elsässer A, Vizcaya D, Michel A, Eberhard S, Schlothauer N, Berg J, Garbe E (2018) The contribution of comorbidities to mortality in hospitalized patients with heart failure. Clin Res Cardiol 107(6):487-497

33. Tschöpe C, Birner C, Böhm M, Bruder O, Frantz S, Luchner A, Maier L, Stork S, Kherad B, Laufs U (2018) Heart failure with preserved ejection fraction: current management and future strategies: expert opinion on the behalf of the Nucleus of the "Heart Failure Working Group" of the German Society of Cardiology (DKG). Clin Res Cardiol 107(1):1-19

34. Haass M, Kitzman DW, Anand IS, Miller A, Zile MR, Massie BM, Carson PE (2011) Body mass index and adverse cardiovascular outcomes in heart failure patients with preserved ejection fraction: results from the Irbesartan in Heart Failure with Preserved Ejection Fraction (I-PRESERVE) trial. Circ Heart Fail 4(3):324-331

35. Hegde SM, Claggett B, Shah AM, Lewis EF, Anand I, Shah SJ, Sweitzer NK, Fang JC, Pitt B, Pfeffer MA, Solomon SD (2017) Physical activity and prognosis in the TOPCAT Trial (Treatment of Preserved Cardiac Function Heart Failure With an Aldosterone Antagonist). Circulation 136(11):982-992

36. Edelmann F, Gelbrich G, Dungen H-D, Frohling S, Wachter R, Stahrenberg R, Binder L, Topper A, Lashki DJ, Schwarz S, Herrmann-Lingen C, Loffler M, Hasenfuss G, Halle M, Pieske B (2011) Exercise training improves exercise capacity and diastolic function in patients with heart failure with preserved ejection 
fraction: results of the Ex-DHF (Exercise training in Diastolic Heart Failure) pilot study. J Am Coll Cardiol 58(17):1780-1791

37. Edelmann F, Bobenko A, Gelbrich G, Hasenfuss G, HerrmannLingen C, Duvinage A, Schwarz S, Mende M, Prettin C, Trippel T, Lindhorst R, Morris D, Pieske-Kraigher E, Nolte K, Dungen H-D, Wachter R, Halle M, Pieske B (2017) Exercise training in Diastolic Heart Failure (Ex-DHF): rationale and design of a multicentre, prospective, randomized, controlled, parallel group trial. Eur J Heart Fail 19(8):1067-1074

38. Kitzman DW, Brubaker P, Morgan T, Haykowsky M, Hundley G, Kraus WE, Eggebeen J, Nicklas BJ (2016) Effect of caloric restriction or aerobic exercise training on peak oxygen consumption and quality of life in obese older patients with heart failure with preserved ejection fraction: a randomized clinical trial. JAMA 315(1):36-46

39. Bekfani T, Pellicori P, Morris D, Ebner N, Valentova M, Sandek A, Doehner W, Cleland JG, Lainscak M, Schulze PC, Anker SD, von Haehling S (2019) Iron deficiency in patients with heart failure with preserved ejection fraction and its association with reduced exercise capacity, muscle strength and quality of life. Clin Res Cardiol 108(2):203-211

40. Anker SD, Kirwan BA, van Veldhuisen DJ, Filippatos G, CominColet J, Ruschitzka F, Lüscher TF, Arutyunov GP, Motro M, Mori C, Roubert B, Pocock SJ, Ponikowski P (2018) Effects of ferric carboxymaltose on hospitalisations and mortality rates in iron-deficient heart failure patients: an individual patient data meta-analysis. Eur J Heart Fail 20(1):125-133

41. Stugiewicz M, Tkaczyszyn M, Kasztura M, Banasiak W, Ponikowski P, Jankowska EA (2016) The influence of iron deficiency on the functioning of skeletal muscles: experimental evidence and clinical implications. Eur J Heart Fail 18(7):762-773

42. von Hardenberg A, Maack C (2017) Mitochondrial therapies in heart failure. Handb Exp Pharmacol 243:491-514

43. Beckett NS, Peters R, Fletcher AE, Staessen JA, Liu L, Dumitrascu D, Stoyanovsky V, Antikainen RL, Nikitin Y, Anderson C, Belhani A, Forette F, Rajkumar C, Thijs L, Banya W, Bulpitt CJ (2008) Treatment of hypertension in patients 80 years of age or older. N Engl J Med 358(18):1887-1898

44. Williams B, Mancia G, Spiering W, Agabiti Rosei E, Azizi M, Burnier M, Clement DL, Coca A, de Simone G, Dominiczak A, Kahan T, Mahfoud F, Redon J, Ruilope L, Zanchetti A, Kerins M, Kjeldsen SE, Kreutz R, Laurent S et al (2018) 2018 ESC/ ESH Guidelines for the management of arterial hypertension. Eur Heart J 39(33):3021-3104

45. Hwang S-J, Melenovsky V, Borlaug BA (2014) Implications of coronary artery disease in heart failure with preserved ejection fraction. J Am Coll Cardiol 63(25 Pt A):2817-2827

46. Sepehri Shamloo A, Bollmann A, Dagres N, Hindricks G, Arya A (2020) Natriuretic peptides: biomarkers for atrial fibrillation management. Clin Res Cardiol. https://doi.org/10.1007/s0039 2-020-01608-x

47. Cikes M, Claggett B, Shah AM, Desai AS, Lewis EF, Shah SJ, Anand IS, O'Meara E, Rouleau JL, Sweitzer NK, Fang JC, Saksena S, Pitt B, Pfeffer MA, Solomon SD (2018) Atrial fibrillation in heart failure with preserved ejection fraction: the TOPCAT trial. JACC Heart Fail 6(8):689-697

48. Di Biase L, Mohanty P, Mohanty S, Santangeli P, Trivedi C, Lakkireddy D, Reddy M, Jais P, Themistoclakis S, Dello Russo A, Casella M, Pelargonio G, Narducci ML, Schweikert R, Neuzil P, Sanchez J, Horton R, Beheiry S, Hongo R et al (2016) Ablation versus amiodarone for treatment of persistent atrial fibrillation in patients with congestive heart failure and an implanted device: results from the AATAC Multicenter Randomized Trial. Circulation 133(17):1637-1644
49. Marrouche NF, Brachmann J, Andresen D, Siebels J, Boersma L, Jordaens L, Merkely B, Pokushalov E, Sanders P, Proff J, Schunkert H, Christ H, Vogt J, Bansch D (2018) Catheter ablation for atrial fibrillation with heart failure. N Engl J Med 378(5):417-427

50. Eitel C, Ince H, Brachmann J, Kuck K-H, Willems S, Gerds-Li J-H, Tebbenjohanns J, Richardt G, Hochadel M, Senges J, Tilz RR (2019) Atrial fibrillation ablation strategies and outcome in patients with heart failure: insights from the German ablation registry. Clin Res Cardiol 108(7):815-823

51. Black-Maier E, Ren X, Steinberg BA, Green CL, Barnett AS, Rosa NS, Al-Khatib SM, Atwater BD, Daubert JP, Frazier-Mills C, Grant AO, Hegland DD, Jackson KP, Jackson LR, Koontz JI, Lewis RK, Sun AY, Thomas KL, Bahnson TD et al (2018) Catheter ablation of atrial fibrillation in patients with heart failure and preserved ejection fraction. Hear Rhythm 15(5):651-657

52. Pitt B, Pfeffer MA, Assmann SF, Boineau R, Anand IS, Claggett B, Clausell N, Desai AS, Diaz R, Fleg JL, Gordeev I, Harty B, Heitner JF, Kenwood CT, Lewis EF, O'Meara E, Probstfield JL, Shaburishvili T, Shah SJ et al (2014) Spironolactone for heart failure with preserved ejection fraction. N Engl J Med 370(15):1383-1392

53. Solomon SD, McMurray JJV, Anand IS, Ge J, Lam CSP, Maggioni AP, Martinez F, Packer M, Pfeffer MA, Pieske B, Redfield MM, Rouleau JL, van Veldhuisen DJ, Zannad F, Zile MR, Desai AS, Claggett B, Jhund PS, Boytsov SA et al (2019) Angiotensinneprilysin inhibition in heart failure with preserved ejection fraction. N Engl J Med 381(17):1609-1620

54. Kaschina E, Unger T (2003) Angiotensin AT1/AT2 receptors: regulation, signalling and function. Blood Press 12(2):70-88

55. McMurray JJV, Ostergren J, Swedberg K, Granger CB, Held P, Michelson EL, Olofsson B, Yusuf S, Pfeffer MA (2003) Effects of candesartan in patients with chronic heart failure and reduced left-ventricular systolic function taking angiotensinconverting-enzyme inhibitors: the CHARM-Added trial. Lancet 362(9386):767-771

56. CONSENSUS Trial Study Group (1987) Effects of enalapril on mortality in severe congestive heart failure. Results of the Cooperative North Scandinavian Enalapril Survival Study (CONSENSUS). N Engl J Med 316(23):1429-1435

57. Yusuf S, Pitt B, Davis CE, Hood WB, Cohn JN (1991) Effect of enalapril on survival in patients with reduced left ventricular ejection fractions and congestive heart failure. $\mathrm{N}$ Engl $\mathrm{J}$ Med 325(5):293-302

58. Massie BM, Carson PE, McMurray JJ, Komajda M, McKelvie $\mathrm{R}$, Zile MR, Anderson S, Donovan M, Iverson E, Staiger C, Ptaszynska A, I-PRESERVE Investigators (2008) Irbesartan in patients with heart failure and preserved ejection fraction. $\mathrm{N}$ Engl J Med 359(23):2456-2467

59. Yusuf S, Pfeffer MA, Swedberg K, Granger CB, Held P, McMurray JJV, Michelson EL, Olofsson B, Östergren J (2003) Effects of candesartan in patients with chronic heart failure and preserved left-ventricular ejection fraction: the CHARM-preserved trial. Lancet 362(9386):777-781

60. Cleland JGF, Tendera M, Adamus J, Freemantle N, Polonski L, Taylor J, Investigators P-C (2006) The perindopril in elderly people with chronic heart failure (PEP-CHF) study. Eur Heart J 27(19):2338-2345

61. Solomon SD, Janardhanan R, Verma A, Bourgoun M, Daley WL, Purkayastha D, Lacourciere Y, Hippler SE, Fields H, Naqvi TZ, Mulvagh SL, Arnold JMO, Thomas JD, Zile MR, Lacourcière Y, Aurigemma GP, Investigators Valsartan in Diastolic Dyfunction (VALIDD) (2007) Effect of angiotensin receptor blockade and antihypertensive drugs on diastolic function in patients with 
hypertension and diastolic dysfunction: a randomised trial. Lancet 369(9579):2079-2087

62. Brown NJ (2005) Aldosterone and end-organ damage. Curr Opin Nephrol Hypertens 14(3):235-241

63. Edelmann F, Wachter R, Schmidt AG, Al E (2013) Effect of spironolactone on diastolic function and exercise capacity in patients with heart failure with preserved ejection fraction. JAMA 309(8):781-791

64. Pfeffer MA, Claggett B, Assmann SF, Boineau R, Anand IS, Clausell N, Desai AS, Diaz R, Fleg JL, Gordeev I, Heitner JF, Lewis EF, O'Meara E, Rouleau JL, Probstfield JL, Shaburishvili T, Shah SJ, Solomon SD, Sweitzer NK et al (2015) Regional variation in patients and outcomes in the treatment of preserved cardiac function heart failure with an aldosterone antagonist (TOPCAT) trial. Circulation 131(1):34-42

65. De Denus S, O'Meara E, Desai AS, Claggett B, Lewis EF, Leclair G, Jutras M, Lavoie J, Solomon SD, Pitt B, Pfeffer MA, Rouleau JL (2017) Spironolactone metabolites in TOPCAT—new insights into regional variation. N Engl J Med 376(17):1690-1692

66. Solomon SD, Claggett B, Lewis EF, Desai A, Anand I, Sweitzer NK, O'meara E, Shah SJ, Mckinlay S, Fleg JL, Sopko G, Pitt B, Pfeffer MA (2016) Influence of ejection fraction on outcomes and efficacy of spironolactone in patients with heart failure with preserved ejection fraction. Eur Heart J. 37(5):455-462

67. Yancy CW, Jessup M, Bozkurt B, Butler J, Casey DEJ, Colvin MM, Drazner MH, Filippatos GS, Fonarow GC, Givertz MM, Hollenberg SM, Lindenfeld J, Masoudi FA, McBride PE, Peterson PN, Stevenson LW, Westlake C (2017) 2017 ACC/AHA/ HFSA focused update of the 2013 ACCF/AHA guideline for the management of heart failure: a report of the American College of Cardiology/American Heart Association Task Force on Clinical Practice Guidelines and the Heart Failure Society of America. Circulation 136(6): e137-e161

68. MERIT HF study group. (1999) Effect of metoprolol CR/XL in chronic heart failure: metoprolol CR/XL randomised intervention trial in congestive heart failure (MERIT-HF). Lancet 353(9169):2001-2007

69. Packer M, Coats AJ, Fowler MB, Katus HA, Krum H, Mohacsi P, Rouleau JL, Tendera M, Castaigne A, Roecker EB, Schultz MK, DeMets DL (2001) Effect of carvedilol on survival in severe chronic heart failure. N Engl J Med 344(22):1651-1658

70. Bramlage P, Swift SL, Thoenes M, Minguet J, Ferrero C, Schmieder RE (2017) Non-steroidal mineralocorticoid receptor antagonism for the treatment of cardiovascular and renal disease. Eur J Heart Fail 19(6):811

71. Martín-Martínez M, Pérez-Gordillo FL, de La Rosa DA, Rodríguez Y, Gerona-Navarro G, González-Muñiz R, Zhou MM (2017) Modulating mineralocorticoid receptor with non-steroidal antagonists. New opportunities for the development of potent and selective ligands without off-target side effects. J Med Chem 60(7):2629-2650

72. Böhm M, Perez A-C, Jhund PS, Reil JC, Komajda M, Zile MR, McKelvie RS, Anand IS, Massie BM, Carson PE, McMurray JJV (2014) Relationship between heart rate and mortality and morbidity in the irbesartan patients with heart failure and preserved systolic function trial (I-Preserve). Eur J Heart Fail 16(7):778-787

73. Takada T, Sakata Y, Miyata S, Takahashi J, Nochioka K, Miura M, Tadaki S, Shimokawa H (2014) Impact of elevated heart rate on clinical outcomes in patients with heart failure with reduced and preserved ejection fraction: a report from the CHART-2 Study. Eur J Heart Fail 16(3):309-316

74. Simpson J, Castagno D, Doughty RN, Poppe KK, Earle N, Squire I, Richards M, Andersson B, Ezekowitz JA, Komajda M, Petrie MC, McAlister FA, Gamble GD, Whalley GA, McMurray JJV (2015) Is heart rate a risk marker in patients with chronic heart failure and concomitant atrial fibrillation? Results from the MAGGIC meta-analysis. Eur J Heart Fail 17(11):1182-1191

75. Van Veldhuisen DJ, Cohen-Solal A, Böhm M, Anker SD, Babalis D, Roughton M, Coats AJS, Poole-Wilson PA, Flather MD (2009) Beta-blockade with nebivolol in elderly heart failure patients with impaired and preserved left ventricular ejection fraction: data From SENIORS (Study of Effects of Nebivolol Intervention on Outcomes and Rehospitalization in Seniors With Heart Failure). J Am Coll Cardiol 53(23):2150-2158

76. Conraads VM, Metra M, Kamp O, De Keulenaer GW, Pieske B, Zamorano J, Vardas PE, Böhm M, Dei CL (2012) Effects of the long-term administration of nebivolol on the clinical symptoms, exercise capacity, and left ventricular function of patients with diastolic dysfunction: results of the ELANDD study. Eur J Heart Fail 14(2):219-225

77. Fukuta H, Goto T, Wakami K, Ohte N (2017) The effect of betablockers on mortality in heart failure with preserved ejection fraction: a meta-analysis of observational cohort and randomized controlled studies. Int J Cardiol 228:4-10

78. Seferovic JP, Claggett B, Seidelmann SB, Seely EW, Packer M, Zile MR, Rouleau JL, Swedberg K, Lefkowitz M, Shi VC, Desai AS, McMurray JJV, Solomon SD (2017) Effect of sacubitril/valsartan versus enalapril on glycaemic control in patients with heart failure and diabetes: a post hoc analysis from the PARADIGMHF trial. Lancet Diabetes Endocrinol 5(5):333-340

79. Solomon SD, Vaduganathan M, Claggett BL, Packer M, Zile M, Swedberg K, Rouleau J, Pfeffer MA, Desai A, Lund LH, Koeber L, Anand I, Sweitzer NK, Linssen G, Merkely B, Arango JL, Vinereanu D, Chen C-H, Senni M et al (2019) Sacubitril/valsartan across the spectrum of ejection fraction in heart failure. Circulation 141(5):352-361

80. Lund LH, Claggett B, Liu J, Lam CS, Jhund PS, Rosano GM, Swedberg K, Yusuf S, Granger CB, Pfeffer MA, McMurray JJV, Solomon SD (2018) Heart failure with mid-range ejection fraction in CHARM: characteristics, outcomes and effect of candesartan across the entire ejection fraction spectrum. Eur J Heart Fail 20(8):1230-1239

81. Cleland JGF, Bunting KV, Flather MD, Altman DG, Holmes J, Coats AJS, Manzano L, McMurray JJV, Ruschitzka F, Van Veldhuisen DJ, Von Lueder TG, Böhm M, Andersson B, Kjekshus J, Packer M, Rigby AS, Rosano G, Wedel H, Hjalmarson $\AA$ et al (2018) Beta-blockers for heart failure with reduced, mid-range, and preserved ejection fraction: an individual patient-level analysis of double-blind randomized trials. Eur Heart J 39(1):26-35

82. McMurray JJV, Jackson AM, Lam CSP, Redfield MM, Anand IS, Ge J, Lefkowitz MP, Maggioni AP, Martinez F, Packer M, Pfeffer MA, Pieske B, Rizkala AR, Sabarwal SV, Shah AM, Shah SJ, Shi VC, van Veldhuisen DJ, Zannad F et al (2020) Effects of sacubitril-valsartan, versus valsartan, in women compared to men with heart failure and preserved ejection fraction: insights from PARAGON-HF. Circulation 141:338-351

83. Reil J-C, Hohl M, Reil G-H, Granzier HL, Kratz MT, Kazakov A, Fries P, Muller A, Lenski M, Custodis F, Graber S, Frohlig G, Steendijk P, Neuberger H-R, Böhm M (2013) Heart rate reduction by If-inhibition improves vascular stiffness and left ventricular systolic and diastolic function in a mouse model of heart failure with preserved ejection fraction. Eur Heart $\mathbf{J}$ 34(36):2839-2849

84. van Bilsen M, Daniels A, Brouwers O, Janssen BJA, Derks WJA, Brouns AE, Munts C, Schalkwijk CG, van der Vusse GJ, van Nieuwenhoven FA (2014) Hypertension is a conditional factor for the development of cardiac hypertrophy in type 2 diabetic mice. PLoS One 9(1):e85078

85. Komajda M, Isnard R, Cohen-Solal A, Metra M, Pieske B, Ponikowski P, Voors AA, Dominjon F, Henon-Goburdhun C, 
Pannaux M, Böhm M (2017) Effect of ivabradine in patients with heart failure with preserved ejection fraction: the EDIFY randomized placebo-controlled trial. Eur J Heart Fail 19(11):1495-1503

86. Pal N, Sivaswamy N, Mahmod M, Yavari A, Rudd A, Singh S, Dawson DK, Francis JM, Dwight JS, Watkins H, Neubauer S, Frenneaux M, Ashrafian H (2015) Effect of selective heart rate slowing in heart failure with preserved ejection fraction. Circulation 132(18):1719-1725

87. Paulus WJ, Tschöpe C, Sanderson JE, Rusconi C, Flachskampf FA, Rademakers FE, Marino P, Smiseth OA, De Keulenaer G, Leite-Moreira AF, Borbely A, Edes I, Handoko ML, Heymans S, Pezzali N, Pieske B, Dickstein K, Fraser AG, Brutsaert DL (2007) How to diagnose diastolic heart failure: a consensus statement on the diagnosis of heart failure with normal left ventricular ejection fraction by the Heart Failure and Echocardiography Associations of the European Society of Cardiology. Eur Heart J 28(20):2539-2550

88. Tschöpe C, Van Linthout S (2014) New insights in (inter)cellular mechanisms by heart failure with preserved ejection fraction. Curr Heart Fail Rep 11(4):436-444

89. Redfield MM, Anstrom KJ, Levine JA, Koepp GA, Borlaug BA, Chen HH, LeWinter MM, Joseph SM, Shah SJ, Semigran MJ, Felker GM, Cole RT, Reeves GR, Tedford RJ, Tang WHW, McNulty SE, Velazquez EJ, Shah MR, Braunwald E (2015) Isosorbide mononitrate in heart failure with preserved ejection fraction. N Engl J Med 373(24):2314-2324

90. Borlaug BA, Koepp KE, Melenovsky V (2015) Sodium nitrite improves exercise hemodynamics and ventricular performance in heart failure with preserved ejection fraction. J Am Coll Cardiol 66(15):1672-1682

91. Eggebeen J, Kim-Shapiro DB, Haykowsky M, Morgan TM, Basu S, Brubaker P, Rejeski J, Kitzman DW (2016) One week of daily dosing with beetroot juice improves submaximal endurance and blood pressure in older patients with heart failure and preserved ejection fraction. JACC Heart Fail 4(6):428-437

92. Borlaug BA, Anstrom KJ, Lewis GD, Shah SJ, Levine JA, Koepp GA, Givertz MM, Felker GM, LeWinter MM, Mann DL, Margulies KB, Smith AL, Tang WHW, Whellan DJ, Chen HH, Davila-Roman VG, McNulty S, Desvigne-Nickens P, Hernandez AF et al (2018) Effect of inorganic nitrite vs placebo on exercise capacity among patients with heart failure with preserved ejection fraction: the INDIE-HFpEF randomized clinical trial. JAMA 320(17):1764-1773

93. Michel LYM, Balligand J-L (2017) New and emerging therapies and targets: beta-3 agonists. Handb Exp Pharmacol 243:205-223

94. Gauthier C, Tavernier G, Charpentier F, Langin D, Le Marec H (1996) Functional beta3-adrenoceptor in the human heart. J Clin Investig 98(2):556-562

95. Belge C, Hammond J, Dubois-Deruy E, Manoury B, Hamelet J, Beauloye C, Markl A, Pouleur A-C, Bertrand L, Esfahani H, Jnaoui K, Gotz KR, Nikolaev VO, Vanderper A, Herijgers P, Lobysheva I, Iaccarino G, Hilfiker-Kleiner D, Tavernier G et al (2014) Enhanced expression of beta3-adrenoceptors in cardiac myocytes attenuates neurohormone-induced hypertrophic remodeling through nitric oxide synthase. Circulation 129(4):451-462

96. Westermann D, Riad A, Richter U, Jager S, Savvatis K, Schuchardt M, Bergmann N, Tolle M, Nagorsen D, Gotthardt M, Schultheiss H-P, Tschöpe C (2009) Enhancement of the endothelial NO synthase attenuates experimental diastolic heart failure. Basic Res Cardiol 104(5):499-509

97. Schiattarella GG, Altamirano F, Tong D, French KM, Villalobos E, Kim SY, Luo X, Jiang N, May HI, Wang ZV, Hill TM, Mammen PPA, Huang J, Lee DI, Hahn VS, Sharma K, Kass DA, Lavandero S, Gillette TG et al (2019) Nitrosative stress drives heart failure with preserved ejection fraction. Nature 568(7752):351-356

98. Redfield MM, Chen HH, Borlaug BA, Semigran MJ, Lee KL, Lewis G, LeWinter MM, Rouleau JL, Bull DA, Mann DL, Deswal A, Stevenson LW, Givertz MM, Ofili EO, O'Connor CM, Felker GM, Goldsmith SR, Bart BA, McNulty SE et al (2013) Effect of phosphodiesterase-5 inhibition on exercise capacity and clinical status in heart failure with preserved ejection fraction: a randomized clinical trial. JAMA 309(12):1268-1277

99. Hoendermis ES, Liu LCY, Hummel YM, van der Meer P, de Boer RA, Berger RMF, van Veldhuisen DJ, Voors AA (2015) Effects of sildenafil on invasive haemodynamics and exercise capacity in heart failure patients with preserved ejection fraction and pulmonary hypertension: a randomized controlled trial. Eur Heart J 36(38):2565-2573

100. Guazzi M, Vicenzi M, Arena R, Guazzi MD (2011) PDE5 inhibition with sildenafil improves left ventricular diastolic function, cardiac geometry, and clinical status in patients with stable systolic heart failure: results of a 1-year, prospective, randomized, placebo-controlled study. Circ Heart Fail 4(1):8-17

101. Filippatos G, Maggioni AP, Lam CSP, Pieske-Kraigher E, Butler J, Spertus J, Ponikowski P, Shah SJ, Solomon SD, Scalise A-V, Mueller K, Roessig L, Bamber L, Gheorghiade M, Pieske B (2017) Patient-reported outcomes in the SOluble guanylate Cyclase stimulatoR in heArT failurE patientS with PRESERVED ejection fraction (SOCRATES-PRESERVED) study. Eur J Heart Fail 19(6):782-791

102. Zinman B, Wanner C, Lachin JM, Fitchett D, Bluhmki E, Hantel S, Mattheus M, Devins T, Johansen OE, Woerle HJ, Broedl UC, Inzucchi SE (2015) Empagliflozin, cardiovascular outcomes, and mortality in type 2 diabetes. N Engl J Med 373(22):2117-2128

103. McMurray JJV, Solomon SD, Inzucchi SE, Kober L, Kosiborod MN, Martinez FA, Ponikowski P, Sabatine MS, Anand IS, Belohlavek J, Böhm M, Chiang C-E, Chopra VK, de Boer RA, Desai AS, Diez M, Drozdz J, Dukat A, Ge J et al (2019) Dapagliflozin in patients with heart failure and reduced ejection fraction. N Engl J Med 381(21):1995-2008

104. Maack C, Lehrke M, Backs J, Heinzel FR, Hulot J-S, Marx N, Paulus WJ, Rossignol P, Taegtmeyer H, Bauersachs J, BayesGenis A, Brutsaert D, Bugger H, Clarke K, Cosentino F, De Keulenaer G, Dei Cas A, Gonzalez A, Huelsmann M et al (2018) Heart failure and diabetes: metabolic alterations and therapeutic interventions: a state-of-the-art review from the Translational Research Committee of the Heart Failure Association-European Society of Cardiology. Eur Heart J 39(48):4243-4254

105. Verma S, McMurray JJV, Cherney DZI (2017) The metabolodiuretic promise of sodium-dependent glucose cotransporter 2 inhibition: the search for the sweet spot in heart failure. JAMA Cardiol 2(9):939-940

106. Pabel S, Wagner S, Bollenberg H, Bengel P, Kovacs A, Schach C, Tirilomis P, Mustroph J, Renner A, Gummert J, Fischer T, Van Linthout S, Tschöpe C, Streckfuss-Bomeke K, Hasenfuss G, Maier LS, Hamdani N, Sossalla S (2018) Empagliflozin directly improves diastolic function in human heart failure. Eur $\mathrm{J}$ Heart Fail 20(12):1690-1700

107. https://www.boehringer-ingelheim.com/press-release/emperialheart-failure-toplineresults. Accessed $31 \mathrm{Dec}$ 2019

108. Inzucchi SE, McGuire DK (2008) New drugs for the treatment of diabetes: part II: incretin-based therapy and beyond. Circulation 117(4):574-584

109. Wei Y, Mojsov S (1995) Tissue-specific expression of the human receptor for glucagon-like peptide-I: brain, heart and pancreatic forms have the same deduced amino acid sequences. FEBS Lett 358(3):219-224 
110. Marso SP, Bain SC, Consoli A, Eliaschewitz FG, Jodar E, Leiter LA, Lingvay I, Rosenstock J, Seufert J, Warren ML, Woo V, Hansen O, Holst AG, Pettersson J, Vilsboll T (2016) Semaglutide and cardiovascular outcomes in patients with type 2 diabetes. $\mathrm{N}$ Engl J Med 375(19):1834-1844

111. Marso SP, Daniels GH, Brown-Frandsen K, Kristensen P, Mann JFE, Nauck MA, Nissen SE, Pocock S, Poulter NR, Ravn LS, Steinberg WM, Stockner M, Zinman B, Bergenstal RM, Buse JB (2016) Liraglutide and cardiovascular outcomes in type 2 diabetes. N Engl J Med 375(4):311-322

112. Graziani F, Varone F, Crea F, Richeldi L (2018) Treating heart failure with preserved ejection fraction: learning from pulmonary fibrosis. Eur J Heart Fail 20(10):1385-1391

113. Yamagami K, Oka T, Wang Q, Ishizu T, Lee J-K, Miwa K, Akazawa H, Naito AT, Sakata Y, Komuro I (2015) Pirfenidone exhibits cardioprotective effects by regulating myocardial fibrosis and vascular permeability in pressure-overloaded hearts. Am J Physiol Heart Circ Physiol 309(3):H512-H522

114. Hartog JWL, Voors AA, Bakker SJL, Smit AJ, van Veldhuisen DJ (2007) Advanced glycation end-products (AGEs) and heart failure: pathophysiology and clinical implications. Eur J Heart Fail 9(12):1146-1155

115. Kasner M, Westermann D, Lopez B, Gaub R, Escher F, Kuhl U, Schultheiss H-P, Tschöpe C (2011) Diastolic tissue Doppler indexes correlate with the degree of collagen expression and cross-linking in heart failure and normal ejection fraction. J Am Coll Cardiol 57(8):977-985

116. Little WC, Zile MR, Kitzman DW, Hundley WG, O'Brien TX, Degroof RC (2005) The effect of alagebrium chloride (ALT-711), a novel glucose cross-link breaker, in the treatment of elderly patients with diastolic heart failure. J Card Fail 11(3):191-195

117. Yang J, Savvatis K, Kang JS, Fan P, Zhong H, Schwartz K, Barry V, Mikels-Vigdal A, Karpinski S, Kornyeyev D, Adamkewicz J, Feng X, Zhou Q, Shang C, Kumar P, Phan D, Kasner M, Lopez B, Diez J et al (2016) Targeting LOXL2 for cardiac interstitial fibrosis and heart failure treatment. Nat Commun 7:13710

118. Kukreja RC, Yin C, Salloum FN (2011) MicroRNAs: new players in cardiac injury and protection. Mol Pharmacol 80(4):558-564

119. Watson CJ, Gupta SK, O'Connell E, Thum S, Glezeva N, Fendrich J, Gallagher J, Ledwidge M, Grote-Levi L, McDonald K, Thum T (2015) MicroRNA signatures differentiate preserved from reduced ejection fraction heart failure. Eur J Heart Fail 17(4):405-415

120. Wong LL, Armugam A, Sepramaniam S, Karolina DS, Lim KY, Lim JY, Chong JPC, Ng JYX, Chen Y-T, Chan MMY, Chen Z, Yeo PSD, Ng TP, Ling LH, Sim D, Leong KTG, Ong HY, Jaufeerally F, Wong R et al (2015) Circulating microRNAs in heart failure with reduced and preserved left ventricular ejection fraction. Eur J Heart Fail 17(4):393-404

121. Dong S, Ma W, Hao B, Hu F, Yan L, Yan X, Wang Y, Chen Z, Wang Z (2014) microRNA-21 promotes cardiac fibrosis and development of heart failure with preserved left ventricular ejection fraction by up-regulating Bcl-2. Int J Clin Exp Pathol 7(2):565-574

122. Van Tassell BW, Trankle CR, Canada JM, Carbone S, Buckley L, Kadariya D, Del Buono MG, Billingsley H, Wohlford G, Viscusi M, Oddi-Erdle C, Abouzaki NA, Dixon D, Biondi-Zoccai G, Arena R, Abbate A (2018) IL-1 blockade in patients with heart failure with preserved ejection fraction. Circ Heart Fail 11(8):e005036

123. Ridker PM, Everett BM, Thuren T, MacFadyen JG, Chang WH, Ballantyne C, Fonseca F, Nicolau J, Koenig W, Anker SD, Kastelein JJP, Cornel JH, Pais P, Pella D, Genest J, Cifkova R, Lorenzatti A, Forster T, Kobalava Z et al (2017) Antiinflammatory therapy with canakinumab for atherosclerotic disease. N Engl J Med 377(12):1119-1131

124. Everett BM, Cornel JH, Lainscak M, Anker SD, Abbate A, Thuren T, Libby P, Glynn RJ, Ridker PM (2019) Anti-inflammatory therapy with canakinumab for the prevention of hospitalization for heart failure. Circulation 139(10):1289-1299

125. Gallet R, de Couto G, Simsolo E, Valle J, Sun B, Liu W, Tseliou E, Zile MR, Marban E (2016) Cardiosphere-derived cells reverse heart failure with preserved ejection fraction (HFpEF) in rats by decreasing fibrosis and inflammation. JACC Basic to Transl Sci $1(1-2): 14-28$

126. Vrtovec B, Frljak S, Jaklic M, Poglajen G, Zemljic G, Cerar A, Haddad F, Wu JC (2018) A pilot trial of CD34+ cell therapy in heart failure with preserved ejection fraction. Circulation 136:A15952

127. Psaltis PJ, Schwarz N, Toledo-Flores D, Nicholls SJ (2016) Cellular therapy for heart failure. Curr Cardiol Rev 12(3):195-215

128. Bertero E, Maack C (2018) Calcium signaling and reactive oxygen species in mitochondria. Circ Res 122(10):1460-1478

129. Sabbah HN, Gupta RC, Kohli S, Wang M, Hachem S, Zhang K (2016) Chronic therapy with elamipretide (MTP-131), a novel mitochondria-targeting peptide, improves left ventricular and mitochondrial function in dogs with advanced heart failure. Circ Heart Fail 9(2):e002206

130. Gibson CM, Giugliano RP, Kloner RA, Bode C, Tendera M, Janosi A, Merkely B, Godlewski J, Halaby R, Korjian S, Daaboul Y, Chakrabarti AK, Spielman K, Neal BJ, Weaver WD (2016) EMBRACE STEMI study: a phase 2a trial to evaluate the safety, tolerability, and efficacy of intravenous MTP-131 on reperfusion injury in patients undergoing primary percutaneous coronary intervention. Eur Heart J 37(16):1296-1303

131. Daubert MA, Yow E, Dunn G, Marchev S, Barnhart H, Douglas PS, O'Connor C, Goldstein S, Udelson JE, Sabbah HN (2017) Novel mitochondria-targeting peptide in heart failure treatment: a randomized, placebo-controlled trial of elamipretide. Circ Heart Fail 10(12):e004389

132. Voors AA, Shah SJ, Bax JJ, Butler J, Gheorghiade M, Hernandez AF, Kitzman DW, McMurray JJV, Wirtz AB, Lanius V, van der Laan M, Solomon SD (2018) Rationale and design of the phase $2 \mathrm{~b}$ clinical trials to study the effects of the partial adenosine A1-receptor agonist neladenoson bialanate in patients with chronic heart failure with reduced (PANTHEON) and preserved (PANACHE) ejection fraction. Eur J Heart Fail 20(11):1601-1610

133. Shah SJ. PANACHE: safety and efficacy of neladenoson bialanate, a partial adenosine A1 receptor agonist, in patients with heart failure and preserved ejection fraction: results from the PANACHE Randomized Controlled Trial. In: Paper presented at 19th annual meeting of the American College of Cardiology; March 16; 2019; New Orleans, LA

134. Parissis JT, Paraskevaidis I, Bistola V, Farmakis D, Panou F, Kourea K, Nikolaou M, Filippatos G, Kremastinos D (2006) Effects of levosimendan on right ventricular function in patients with advanced heart failure. Am J Cardiol 98(11):1489-1492

135. Grossman NL, Fiack CA, Weinberg JM, Rybin DV, Farber HW (2015) Pulmonary hypertension associated with heart failure with preserved ejection fraction: acute hemodynamic effects of inhaled iloprost. Pulm Circ 5(1):198-203

136. Adamson PB, Abraham WT, Aaron M, Aranda JMJ, Bourge RC, Smith A, Stevenson LW, Bauman JG, Yadav JS (2011) CHAMPION trial rationale and design: the long-term safety and clinical efficacy of a wireless pulmonary artery pressure monitoring system. J Card Fail 17(1):3-10

137. Verdejo HE, Castro PF, Concepcion R, Ferrada MA, Alfaro MA, Alcaino ME, Deck CC, Bourge RC (2007) Comparison of a radiofrequency-based wireless pressure sensor to swan-ganz 
catheter and echocardiography for ambulatory assessment of pulmonary artery pressure in heart failure. J Am Coll Cardiol 50(25):2375-2382

138. Castro PF, Concepcion R, Bourge RC, Martinez A, Alcaino M, Deck C, Ferrada M, Alfaro M, Perrone S (2007) A wireless pressure sensor for monitoring pulmonary artery pressure in advanced heart failure: initial experience. J Heart Lung Transplant 26(1):85-88

139. Abraham WT, Stevenson LW, Bourge RC, Lindenfeld JA, Bauman JG, Adamson PB (2016) Sustained efficacy of pulmonary artery pressure to guide adjustment of chronic heart failure therapy: complete follow-up results from the CHAMPION randomised trial. Lancet 387(10017):453-461

140. Shavelle DM. Pulmonary artery pressure-guided therapy for ambulatory heart failure patients in clinical practice: 1-year outcomes from the CardioMEMS Post-Approval Study. In: Paper presented at 19th annual meeting of the American College of Cardiology; March 16; 2019; New Orleans, LA

141. Lutembacher R (1916) De la tenose mitrale avec communication interauirulaier. Arch Mal Coeur Vaiss 9:237-260

142. Sondergaard L, Reddy V, Kaye D, Malek F, Walton A, Mates M, Franzen O, Neuzil P, Ihlemann N, Gustafsson F (2014) Transcatheter treatment of heart failure with preserved or mildly reduced ejection fraction using a novel interatrial implant to lower left atrial pressure. Eur J Heart Fail 16(7):796-801

143. Hasenfuss G, Hayward C, Burkhoff D, Silvestry FE, McKenzie S, Gustafsson F, Malek F, Van der Heyden J, Lang I, Petrie MC, Cleland JGF, Leon M, Kaye DM (2016) A transcatheter intracardiac shunt device for heart failure with preserved ejection fraction (REDUCE LAP-HF): a multicentre, open-label, single-arm, phase 1 trial. Lancet 387(10025):1298-1304

144. Shah SJ, Feldman T, Ricciardi MJ, Kahwash R, Lilly S, Litwin S, Nielsen CD, van der Harst P, Hoendermis E, Penicka M, Bartunek J, Fail PS, Kaye DM, Walton A, Petrie MC, Walker N, Basuray A, Yakubov S, Hummel SL et al (2018) One-year safety and clinical outcomes of a transcatheter interatrial shunt device for the treatment of heart failure with preserved ejection fraction in the reduce elevated left atrial pressure in patients with heart failure (REDUCE LAP-HF I) trial: a randomized clinical trial. JAMA Cardiol 3(10):968-977

145. Morris DA, Vaz Perez A, Blaschke F, Eichstadt H, Ozcelik C, Haverkamp W (2012) Myocardial systolic and diastolic consequences of left ventricular mechanical dyssynchrony in heart failure with normal left ventricular ejection fraction. Eur Heart J Cardiovasc Imaging 13(7):556-567

146. Biering-Sorensen T, Shah SJ, Anand I, Sweitzer N, Claggett B, Liu L, Pitt B, Pfeffer MA, Solomon SD, Shah AM (2017) Prognostic importance of left ventricular mechanical dyssynchrony in heart failure with preserved ejection fraction. Eur J Heart Fail 19(8):1043-1052

147. Tschöpe C, Kherad B, Klein O, Lipp A, Blaschke F, Gutterman D, Burkhoff D, Hamdani N, Spillmann F, Van Linthout S (2019) Cardiac contractility modulation: mechanisms of action in heart failure with reduced ejection fraction and beyond. Eur J Heart Fail 21(1):14-22

148. Tschöpe C, Van Linthout S, Spillmann F, Klein O, Biewener S, Remppis A, Gutterman D, Linke WA, Pieske B, Hamdani N,
Roser M (2016) Cardiac contractility modulation signals improve exercise intolerance and maladaptive regulation of cardiac key proteins for systolic and diastolic function in HFpEF. Int J Cardiol 203:1061-1066

149. Krum H, Schlaich M, Whitbourn R, Sobotka PA, Sadowski J, Bartus K, Kapelak B, Walton A, Sievert H, Thambar S, Abraham WT, Esler M (2009) Catheter-based renal sympathetic denervation for resistant hypertension: a multicentre safety and proofof-principle cohort study. Lancet 373(9671):1275-1281

150. Esler MD, Krum H, Sobotka PA, Schlaich MP, Schmieder RE, Böhm M (2010) Renal sympathetic denervation in patients with treatment-resistant hypertension (The Symplicity HTN-2 Trial): a randomised controlled trial. Lancet 376(9756):1903-1909

151. Donazzan L, Mahfoud F, Ewen S, Ukena C, Cremers B, Kirsch C-M, Hellwig D, Eweiwi T, Ezziddin S, Esler M, Böhm M (2016) Effects of catheter-based renal denervation on cardiac sympathetic activity and innervation in patients with resistant hypertension. Clin Res Cardiol 105(4):364-371

152. Brandt MC, Mahfoud F, Reda S, Schirmer SH, Erdmann E, Böhm M, Hoppe UC (2012) Renal sympathetic denervation reduces left ventricular hypertrophy and improves cardiac function in patients with resistant hypertension. J Am Coll Cardiol 59(10):901-909

153. Mahfoud F, Urban D, Teller D, Linz D, Stawowy P, Hassel J-H, Fries P, Dreysse S, Wellnhofer E, Schneider G, Buecker A, Schneeweis C, Doltra A, Schlaich MP, Esler MD, Fleck E, Böhm M, Kelle S (2014) Effect of renal denervation on left ventricular mass and function in patients with resistant hypertension: data from a multi-centre cardiovascular magnetic resonance imaging trial. Eur Heart J 35(33):2224-2231

154. Schirmer SH, Sayed MMYA, Reil J-C, Lavall D, Ukena C, Linz D, Mahfoud F, Böhm M (2015) Atrial remodeling following catheter-based renal denervation occurs in a blood pressureand heart rate-independent manner. JACC Cardiovasc Interv 8(7):972-980

155. Patel HC, Rosen SD, Hayward C, Vassiliou V, Smith GC, Wage RR, Bailey J, Rajani R, Lindsay AC, Pennell DJ, Underwood SR, Prasad SK, Mohiaddin R, Gibbs JSR, Lyon AR, Di Mario C (2016) Renal denervation in heart failure with preserved ejection fraction (RDT-PEF): a randomized controlled trial. Eur J Heart Fail 18(6):703-712

156. Yip GWK, Wang M, Wang T, Chan S, Fung JWH, Yeung L, Yip T, Lau S-T, Lau C-P, Tang M-O, Yu C-M, Sanderson JE (2008) The Hong Kong diastolic heart failure study: a randomised controlled trial of diuretics, irbesartan and ramipril on quality of life, exercise capacity, left ventricular global and regional function in heart failure with a normal ejection fraction. Heart 94(5):573-580

157. Seferovic PM, Ponikowski P, Anker SD, Bauersachs J, Chioncel O, Cleland JGF, de Boer RA, Drexel H, Ben Gal T, Hill L, Jaarsma T, Jankowska EA, Anker MS, Lainscak M, Lewis BS, McDonagh T, Metra M, Milicic D, Mullens W et al (2019) Clinical practice update on heart failure 2019: pharmacotherapy, procedures, devices and patient management. An expert consensus meeting report of the Heart Failure Association of the European Society of Cardiology. Eur J Heart Fail 21(10):1169-1186 